\title{
Effects of STEM applications on the scientific process skills and performance of secondary school students ${ }^{1}$
}

\author{
Özge Köngül ${ }^{2}$ \\ Mehtap Yildırım ${ }^{3}$
}

\begin{abstract}
In this study, it was aimed to examine the effect of STEM applications on the scientific process skills and process performance of 6th grade secondary school students. In the study concurrent nested mixed research design was used. The sample of the study consists of 35 6th grade students studying at a public school in the district of Küçükçekmece, Istanbul in the 20182019 academic year. Four practices, three STEM lesson plans and one pre-activity plan, developed by the researchers, were implemented for six weeks. Science was taught with the 5E learning model supported by STEM applications. The "Scientific Process Skills Test" was applied to the students as a pre and post test. In order to learn the STEM performance of the students in the learning process, the "Activity Sheet" was applied to the students during the application process. Scientific Process Skills Test was used as a data collection tool in the quantitative part of the
\end{abstract}

\section{Özet}

$\mathrm{Bu}$ araştırmada, STEM uygulamalarının ortaokul altıncı sınıf öğrencilerinin bilimsel süreç becerilerine ve STEM performanslarına olan etkisinin incelenmesi amaçlanmıştır. Araştırmada eşzamanlı iç içe karma araştırma deseni kullanılmıstır. Araştırmanın çalışma grubunu 2018-2019 eğitim-öğretim yllında İstanbul Küçükçekmece ilçesinde bir devlet okulunda okuyan 35 öğrenci oluşturmaktadır. Araştırmacılar tarafindan geliştirilen üç STEM ders planı ve bir ön etkinlik planı olmak üzere dört uygulama, altı hafta süreyle uygulanmıştr. Çalışma grubu öğrencilerine STEM uygulamaları ile desteklenmiş fen öğretimi $5 \mathrm{E}$ modeli kapsamında verilmiştir. Etkinlikler sınıf ortamında ve sınıf dişı alanda gerçekleştirilmiştir. Öğrencilere "Bilimsel Süreç Becerileri Testi" ön ve son test olarak uygulanmıştır. Öğrencilerin öğrenme sürecindeki STEM performanslarını ögrenebilme amacıyla "Etkinlik Kâğıdı"

\footnotetext{
${ }^{1}$ This article is derived from Özge KONGUL's master thesis entitled " Investigation of the effect of science, technology, engineering and mathematics (STEM) applications on the problem solving skills and scientific process skills of the $6^{\text {th }}$ grade students " which was conducted under the supervision of Mehtap YILDIRIM.

2 Ph.D. Student, Marmara University, Faculty of Atatürk Education, Science Education Department, ozgekongul@gmail.com (iD) Orcid ID: 0000-0002-8535-2851

3 Assoc. Prof. Dr., Marmara University, Faculty of Atatürk Education, Science Education Department, mehtap.yildirim@marmara.edu.tr (D) Orcid ID: 0000-0001-7398-8396
} 
research. In the qualitative part, activity papers were used. While the data obtained in the scientific process skills test were analyzed using a statistics program, the activity papers were analyzed with descriptive analysis. As a result of the study, it was seen that science teaching supported by STEM applications positively affected the scientific process skills and improved the process performance of the students positively.

Keywords: Science education, STEM, scientific process skills, STEM performance, secondary school students.

(Extended English summary is at the end of this document) uygulama sürecinde öğrencilere uygulanmıştır. Veri toplama aracı olarak araşturmanın nicel kısmında Bilimsel Süreç Becerileri Testi kullanılmış ve veriler bir istatistik programı kullanılarak analiz edilmiştir. Çalışmanın nitel kısmında ise uygulama ile ilgili etkinlik kâğıtlanı kullanılmış ve betimsel analiz ile incelenmiştir. Araştırmanın sonucunda STEM uygulamaları ile desteklenmiş fen öğretiminin öğrencilerin bilimsel süreç becerilerinde anlamlı farklılık yarattığ ve STEM performanslarını olumlu yönde etkilediği görülmüştür.

Anahtar Kelimeler: Fen eğitimi, STEM, bilimsel süreç becerileri, STEM performans, ortaokul öğrencileri.

\section{Giriş}

Yaşadığımız çă̆, bilim ve teknoloji çağıdır. Hızla gelişen bilim ve teknolojiyle birlikte insanoğlunun yaşamının değişmesi de kaçınılmazdır. İnsanların değişen koşullara uyum sağlayabilmesi de son derece önemlidir. Bu uyum sürecini geçirebilmesi için insanların yenilikçi düşünme, araştırma, sorgulama, karar verme, problem çözme becerileri kazanması gerekir (Yamak, Bulut \& Dündar, 2014).

Günümüzde ülkeler arası güç dengesini ekonomi, siyasi askeri etmenlerin yanı sıra ülkenin yüz ölçümü, nüfusu, tarımsal bölgenin yoğunluğu gibi etmenler belirler. Ancak yüz ölçümü küçük olan veya nüfusu az olan ülkelerin de dünyadaki güç dengesinde rol oynadığ1 görülmektedir. 21.yüzyllda ülkelerin gücünü belirleyen en önemli faktör teknolojik gelişmişlik düzeyidir (Ercan, 2014). Bu sebepten dolayı ülkeler bilim ve teknoloji alanında güçlü olabilmek için yarışa girmişlerdir. 21. yüzyılda üretici bir toplum oluşturmak için mühendislik becerilerine sahip bireyler yetiştirebilmek daha da elzem olmaya başlamıştır (Chachashvili-Bolotin, Milner-Bolotin \& Lissitsa, 2016). Bu nedenle öğretim programlarına mühendislik becerilerinin kazandırılmasına yönelik kazanımlar okul öncesi dönemden başlayarak ele alınmalı ve çocuklar erken yaşlardan itibaren STEM ile tanıştırılmalıdırlar (Çetin \& Demircan, 2020). Fen, teknoloji, matematik ve mühendislik alanlarının etkileşim içinde olduğu STEM (Science (Fen), Technology (Teknoloji), Engineering (Mühendislik), Mathematics (Matematik)) yaklaşımı, son dönemin en popüler ve ilgi gören yaklaşımı olmaya devam etmektedir.

Fen öğretimi ile günlük hayatta karşılaştıkları problemleri bilimsel yollarla çözebileceklerini kavrayan, iyi gözlem yapabilen, yaptkkları inceleme ve araştırmalardan sonuç çıkarıp yorum yapabilen bireylerin yetiştirilmesi hedeflenmektedir. Bu hedefler ile 21. yüzyıl becerilerine ve bilimsel süreç becerilerine sahip bireyler yetiştirilmiş olur (Hançer, Şensoy \& Yıldırım, 2003). Bilimsel süreç becerileri, fen öğrenmeyi kolaylaştıran, araştırma yol ve yöntemlerini kazandıran, öğrencilerin aktif olmasını sağlayan, kendi öğrenmelerinde sorumluluk duygusunu geliştiren ve öğrenmenin kalıcıllı̆̆ını arttıran temel beceriler olarak söylenebilir (YÖK/Dünya Bankası, 1997).

2018 Fen Bilimleri Öğretim Programı incelendiğinde; öğrencilerin doğayı anlaması insançevre ilişkilerini anlaşılması sürecinde ve günlük yaşam sorunlarını çözerken fen bilimlerine ilişkin bilgi ve bilimsel süreç becerilerini kullanması beklenir. Öğretim programında alana özgü beceriler olarak bilimsel süreç becerileri (BSB) ile mühendislik ve tasarım becerileri yer almaktadır. Bu iki alan birbirleriyle ilişkilidir. BSB, bilgiyi elde etme yollarından biridir ve bu süreçte bireyin bilgiyi öğrenmek için gözlem ve araştırma yapması, neden-sonuç ilişkisini kurması, çıkarım yapması gibi becerilerini geliştirmektedir. STEM uygulamaları sürecinde de bu becerilerin sıklıkla kullanılması gerekmektedir. 
Köngül, Ö., \& Yildırım, M. (2021). Title in article's language. Journal of Human Sciences, 18(2), 159-184. doi:10.14687/jhs.v18i2.6066

Çünkü STEM uygulamaları sırasında problemi doğrudan vermek yerine çeşitli senaryo ve kavram karikatürleri yoluyla bireyin merakını uyandıracak şekilde verilmesi bu merakla öğrencinin araştırma yapması ve problemi çözmek için öneriler geliştirip gözlemler yapıp yorumlaması ve ürünler tasarlaması beklenmektedir. Bu sebeple STEM uygulamalarının bireylerin bilimsel süreç becerilerini geliştirmesi düşünülmektedir.

Alanyazın incelendiğinde son yıllarda STEM çalışmalarının sayısında artış olduğu görülmüştür; araştırmacıların STEM uygulamalarının akademik başarıya (İzgi, 2020), kalıcıllğa (Karadeniz, 2019), STEM tutumuna (Şirin, 2020) ve STEM kariyer alanlarına ilgisine (Daymaz, 2019) yoğunlaştıkları görülmüştür. Bununla beraber araştırmacıların, 21. yüzyıl becerileri, öğrencilerin öz yeterliliklerini ve bilimsel yaratıcılıklarını incelemeye başladığı görülmüştür (Benek, 2019; Değirmenci, 2020; Sarıçam ve Yıldırım, 2021). Bu çalışmada, STEM uygulamaları ile desteklenmiş fen öğretiminin altıncı sınıf öğrencilerinin bilimsel süreç becerilerine etkisi olup olmadığı ve süreç içerisinde öğrencilerin STEM ile ilgili performanslarının nasıl olduğunun ortaya çıkarılması hedeflenmiştir. STEM uygulamalarının bilimsel süreç becerisine etkisi okul öncesi öğrencileri (Ünal, 2019), ilkokul öğrencileri (Kavak, 2019), ortaokul öğrencileri (Yılmaz, 2019; İzgi, 2020) ve öğretmenler (Kale, 2019) gibi farklı örneklemlerde incelenmiştir. Öğrencilerinin STEM performanslarının incelenmesi alanyazında sayı olarak az olmakla birlikte mevcuttur (Şen, 2018; Smith, Hao, Dennen, vd., 2020).

\section{Problem Durumu}

Bu çalışmada, "STEM uygulamaları ile desteklenmiş fen öğretiminin ortaokul altıncı sınıf öğrencilerinin bilimsel süreç becerilerine ve STEM ile ilgili performanslarına etkisi nasıldır? sorusu doğrultusunda aşağıdaki alt problemlere göre araştırma yapilmıştır;

1) STEM uygulamaları ile desteklenmiş fen öğretiminin ortaokul altıncı sınıf öğrencilerinin bilimsel süreç becerilerine etkisi var mıdır?

2) Ortaokul altıncı sınıf öğrencilerinin STEM uygulamaları ile desteklenmiş fen öğretim sürecindeki performansları nasildır?

\subsection{Araştırma Deseni}

\section{Yöntem}

$\mathrm{Bu}$ araştırmada nitel ve nicel araşturma yöntemlerinin birlikte kullanıldı̆̆ı karma yöntem kullanılmıştır. Karma yöntem, genellikle her iki yaklaşımın sınırlılıklarını en aza indirme amacıyla kullanılmaktadır. Araştırmacının nitel ve nicel verilere ulaşabilme imkânı varsa kullanılacak ideal bir yaklaşımdır (Creswell, 2014).

Bu çalışmada STEM uygulamaları ile desteklenmiş fen öğretiminin altıncı sınıf öğrencilerinin bilimsel süreç becerileri üzerindeki etkisini incelemek için eşzamanlı iç içe karma desen (Şekil 1) kullanılmıştır. Bu, nitel ve nicel verilerin aynı anda veya sırayla toplanabildiği bir yöntemdir ve aynı zamanda bir veri türünün başka bir veri türüne gömülmesine de izin verir (Creswell ve Plano Clark, 2014). Bu çalışmada, nitel veriler nicel veriler "NICEL (+ nitel)" içine yerleştirilmiştir. Araştırmanın nicel aşamasında ön test-son test tek gruplu desen kullanılmıştır. Nitel veriler ise uygulama sırasında etkinlik kâğıtları ile toplanmıştır. Deneysel araştırmalarda en temel amaç; belirlenen ve uygulanan bir durumu, sonucu veya bağımlı değişkeni etkileyip etkilemediğini belirlemektir. Bağımlı ve bağımsız değişkenler arasında neden-sonuç ilişkisi kurulmaya çalışılmaktadır. Bunun için bağımlı değişken dışında tüm değişkenler kontrol altında tutulur. Bağımsız değişken bağımlı değişkeni etkilediğinde buna bağımsız değişkenin bağımlı değişkene sebep olduğu söylenebilir (Büyüköztürk, Kılıç Çakmak, Akgün, Karadeniz \& Demirel, 2019). Bu araştırmada ön test-son test tek gruplu desen kullanılmıştır. Bu desende yapılan deneysel işlemin etkisi tek grup üzerindeki çalışma ile gözlenmektedir. Deneklerin bağımlı değişkene ilişkin ölçümlerini elde edebilmek için ön test ve son test olarak aynı gruba aynı ölçme araçları kullanılmaktadır ve bu desende seçkisizlik ve eşleştirme yoktur (Büyüköztürk vd., 2019). 
Köngül, Ö., \& Yıldırım, M. (2021). Title in article's language. Journal of Human Sciences, 18(2), 159-184. doi: $10.14687 /$ jhs.v18i2.6066

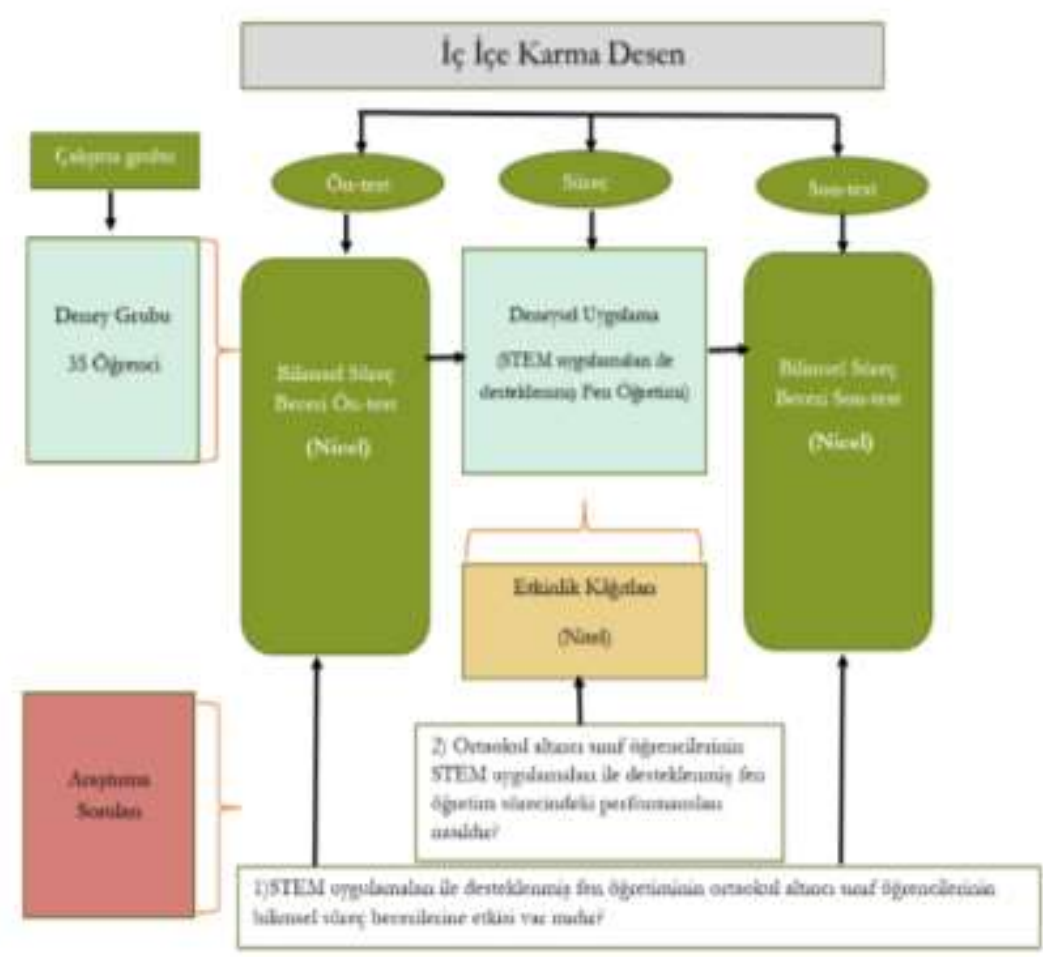

Şekil 1. Araştırma Deseni

Tablo 1. Çalışma Desenine Ait Simgesel Model

\begin{tabular}{llll}
\hline Grup & Ön test & İşlem & Son test \\
\hline $\mathrm{G}$ & $\mathrm{O}_{1.1}$ & $\mathrm{X}_{\mathrm{R} 1, \mathrm{R} 2 \mathrm{R} 3}$ & $\ddot{O}_{1.2}$ \\
\hline
\end{tabular}

$\mathrm{O}_{1}$ : Bilimsel Süreç Becerileri Testi

X: STEM Etkinlikleri ile Desteklenmiş Fen Öğretimi

$\mathrm{R}_{1,2,3}$ : Etkinlik Kâğtları

\section{2. Çalışma Grubu}

Bu çalışma grubunu, 2018-2019 eğitim öğretim yllı bahar döneminde İstanbul ili Küçükçekmece ilçesinde bir ortaokul altıncı sinıfinda öğrenim görmekte olan 35 öğrenci oluşturmaktadır. Öğrenciler okuldaki mevcut sınıflardan birinde tek grupla gerçekleştirilmiştir. $\mathrm{Bu}$ grup kolay ulaşılabilir örnekleme uygun olarak seçilmiştir çünkü araştırmacılardan biri aynı zamanda bu sınıfın fen bilimleri öğretmenidir. Çalışmalarda kolay ulaşılabilirlik olmak araştırmaya hız ve pratiklik sağlar (Büyüköztürk, 2007).

Uygulama için İstanbul ili Küçükçekmece ilçesindeki bir ortaokulun altıncı sınıfları arasından akademik başarıları ve öğretmen görüşleri göz önüne alınarak ortalama bir sınıf olan 6/E sınıfı kolay ulaşılabilir örnekleme uygun olarak çalışma için seçilmiştir. Mevcudu 38 kişi olan 6/E şubesinden araştırmanın ön testine ve son testine girmeyen 2 öğrenci ve sınıf değişikliği sebebiyle araştırmayı tamamlayamayan 1 öğrenci çalışmadan çıkarılmıştır. Sonuç olarak çalışmaya 18'i kız, 17'si erkek olmak üzere 35 öğrenci katılmıştır.

\subsection{Veri Toplama Araçları}

Araştırmada kullanılan veri toplama araçları olarak "Bilimsel Süreç Becerileri Testi" ve "Etkinlik Kâğıtları" kullanılmıştır. Araştırmada çalışma grubuna uygulanan veri toplama araçları Tablo 2'de verilmiştir. 
Köngül, Ö., \& Yıldırım, M. (2021). Title in article's language. Journal of Human Sciences, 18(2), 159-184. doi:10.14687/jhs.v18i2.6066

Tablo 2. Çalışma Grubuna Uygulanan Ölçme Araçları

\begin{tabular}{llll}
\hline Alt Problemler & $\begin{array}{l}\text { Veri } \\
\text { Toplama } \\
\text { Aracı }\end{array}$ & $\begin{array}{l}\text { Veri } \\
\text { Analizi }\end{array}$ & $\begin{array}{l}\text { Veri } \\
\text { Toplama } \\
\text { Süreci }\end{array}$ \\
\hline $\begin{array}{l}\text { 1) STEM uygulamaları ile desteklenmiş fen öğretiminin } \\
\text { ortaokul altıncı sınıf öğrencilerinin bilimsel süreç } \\
\text { becerilerine etkisi var mıdır? }\end{array}$ & BSB Testi & Nicel & $\begin{array}{l}\text { Uygulama } \\
\text { Başında ve } \\
\text { Sonunda }\end{array}$ \\
$\begin{array}{l}\text { 2) Ortaokul altıncı sınıf öğrencilerinin STEM } \\
\text { uygulamaları ile desteklenmiş fen öğretim sürecindeki } \\
\text { performansları nasıldır? }\end{array}$ & Kâğılik & Nitel & $\begin{array}{l}\text { Uygulama } \\
\text { Sürecinde }\end{array}$ \\
\hline
\end{tabular}

\subsubsection{Bilimsel Süreç Becerileri Testi}

Araştırmada uygulanan Bilimsel Süreç Becerileri Testi'nin orjinali Burns, Okey ve Wise (1985) tarafından geliştirilmiştir. Bu testin Türkçe'ye çevrilip uyarlanması Özkan, Aşkar ve Geban (1992) tarafından yapılmıştır. Orijinal olan testin KR-20 güvenilirlik katsayısı 0.86 'dır. Testin bilişsel düzey olarak sekizinci sınıf öğrencilerine uygun olduğu görülmüştür (Özkan, Aşkar \& Geban, 1992, akt. Kara, 2017). Çakar (2008) yaptığı çalışmada bu testi beşinci sınıf öğrencilerine uygulamıştır. Bu yüzden testte bulunan maddeler tekrar düzenlenmiştir. Testin maddeleri beşinci sınıf fen bilimleri programına ve öğrencilerin bilişsel düzeylerine göre düzenlenmiştir. Beşinci sınıf fen bilimleri programında yer alan 24 adet bilimsel süreç becerileri kazanımlarını kapsaması sağlanacak şekilde oluşturulmuştur. Bilimsel süreç becerileri testi geçerliliğinin sağlanması için bir uzmandan görüşü alınmış ve beş adet fen bilimleri öğretmenin de görüşüne başvurulmuştur. Sorular 4 seçenekli olarak düzenlenmiştir. Testte yer alan maddelerin ayırt edicilik gücü indeksleri 0.31 ile 0.73 arasındadır. Madde güçlük indeksleri ise 0.36 ile 0.79 arasındadır (Çakar, 2008). Bu çalışmada da Çakar (2008)'in düzenlediği hali BSB testi olarak kullanılmıştır.

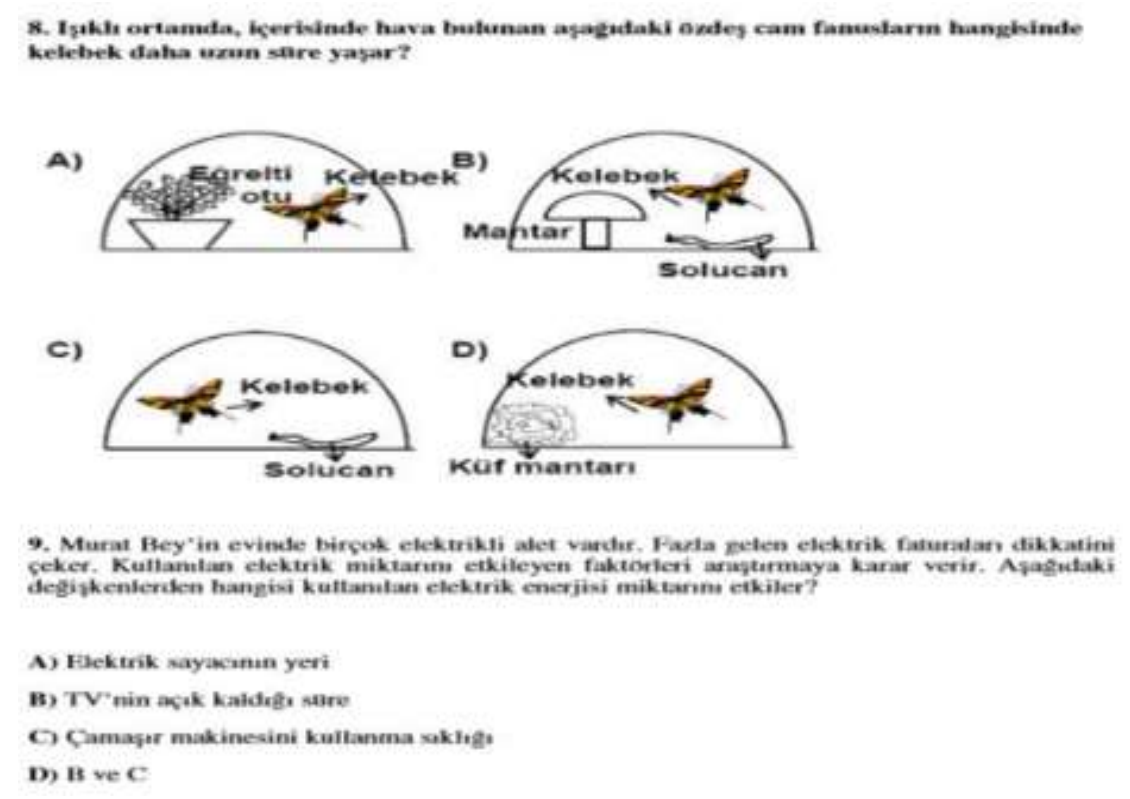

Şekil 2. Bilimsel Süreç Becerileri Testi'ne İlişkin Örnek Sorular 
Köngül, Ö., \& Yıldırım, M. (2021). Title in article's language. Journal of Human Sciences, 18(2), 159-184. doi:10.14687/jhs.v18i2.6066

\subsubsection{Etkinlik Kâğıdı}

Ortaokul altıncı sınıf öğrencilerinin STEM uygulamalanı ile desteklenmiş fen öğretim sürecindeki STEM performansları nasıldır?" sorusuna cevap vermesi amacıyla "Etkinlik Kâğıdı" hazırlanmıştır. Etkinlik kâğıdı, araştırma sürecinde yapılan her bir etkinlik için ayrı hazırlanmıştır. Bir tanesi uygulama öncesi ön etkinlik için olmak üzere toplam dört tane hazırlanmış ve uygulanmıştır. Etkinlik kâğıtlarıyla toplam 15 STEM performansı (Tablo 7) ölçülmüştür. Araştırmacılar tarafindan hazırlanan etkinlik kâğtları, öğrencilerin istenilen STEM performansına ulaşabilmesi amaciyla oluşturulmuştur. Etkinlik kâğ̣tları uzman görüşüne sunularak kullanılmıştır.

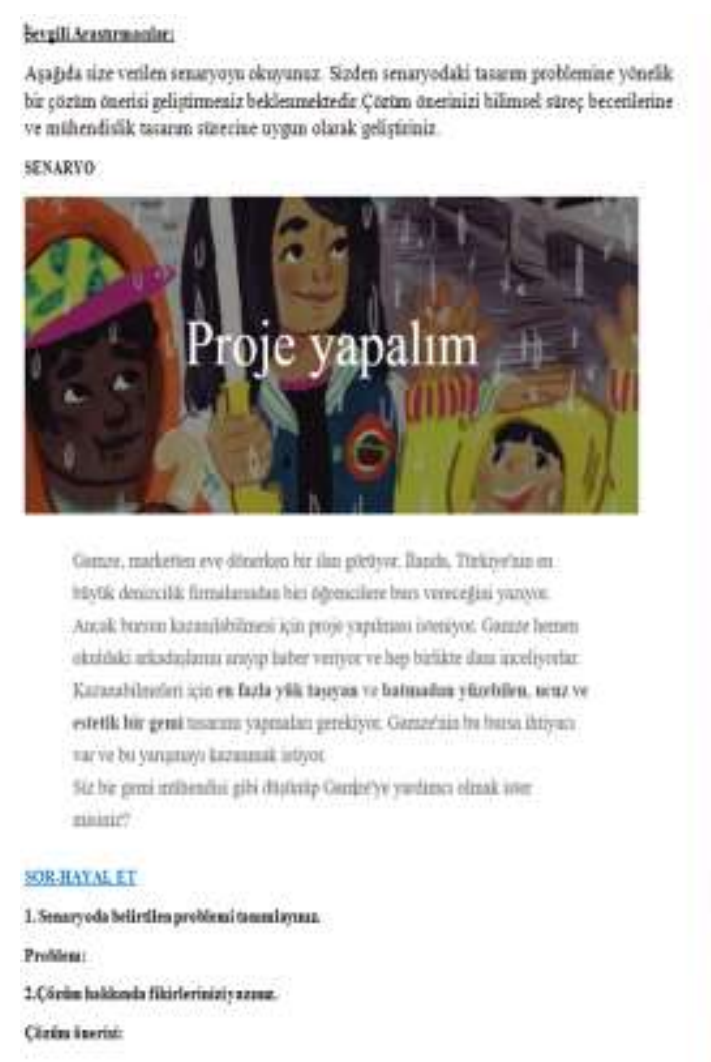

mates

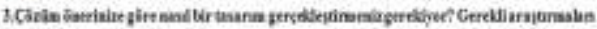

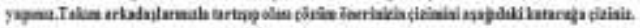

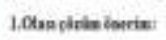

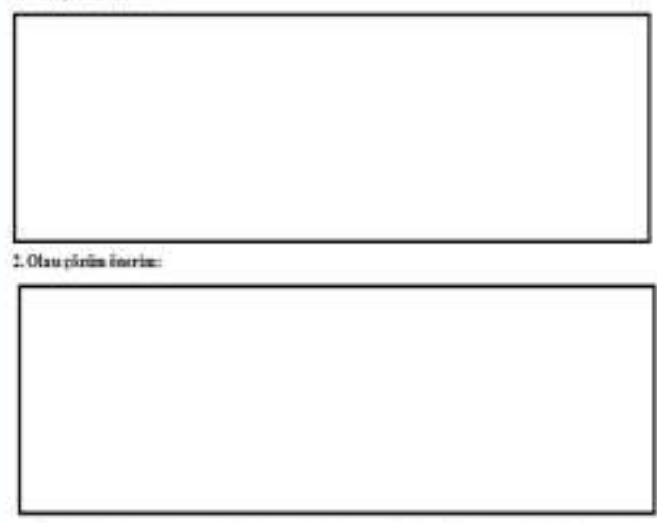

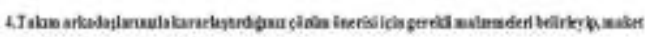

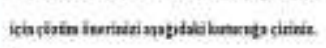

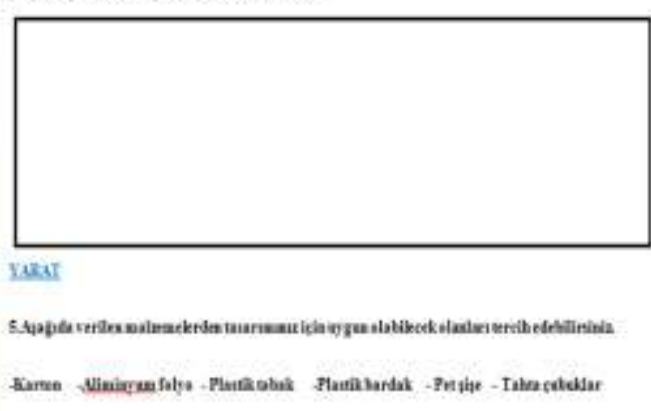

\subsection{Uygulama}

Şekil 3. Etkinlik Kâğıdına İlişkin Örnek Sorular

Araştırma altıncı sınıf "Kuvvet ve Hareket" ünitesi kapsamında yapılmıştır. Uygulamada çalışma grubu öğrencilerine uygulama öncesinde "Bilimsel Süreç Becerileri Testi" ön test olarak uygulanmıştır. Çalışma grubu öğrencileri gruplara ayrılmıştır. Uygulama beş kişiden oluşan beş grup ve altı kişiden oluşan bir grup olmak üzere toplam altı grupla yapılmıştır. Gruplara öğrenci seçimi yapılırken birinci dönem karne notları, öğretmen görüşleri ve gruplardaki cinsiyet dağılımı göz önünde bulundurulmuş ve grupların birbirine denk olması dikkate alınarak uygulamaya geçilmiştir.

Uygulama altı haftalık süreç içerisinde gerçekleşmiştir. İlk hafta ön testlerin uygulanması ile ve sonraki iki hafta ön uygulama ile geçmiştir. Ön uygulamanın ilk haftası grupların oluşumu, sınıf sıra düzeni ile geçmiş sonraki hafta STEM ön uygulaması yapılmıştır. Ön uygulama öğrencilere, STEM çalışmasını nasıl yapılacağını ve etkinlik kâğıtlarının nasıl doldurulacağını göstermek için yapılmış olup verileri kullanılmamıştır. Veri toplamak için ise üç ayrı STEM etkinliği yapılmış ve her biri birer hafta sürmüştür. Ön uygulama ile birlikte toplam dört etkinlik yapılmıştır. Çalışma grubu öğrencilerine STEM uygulamaları ile desteklenmiş fen öğretimi 5E öğrenme modeli kapsamında verilmiştir. Etkinlikler duruma göre sınıf ortamında veya sınıf dışı alanda gerçekleştirilmiştir. Uygulama sonunda öğrencilere "Bilimsel Süreç Becerileri Testi" son test olarak uygulanmıştır. 
Köngül, Ö., \& Yıldırım, M. (2021). Title in article's language. Journal of Human Sciences, 18(2), 159-184. doi:10.14687/jhs.v18i2.6066

Öğrencilerin uygulama sürecindeki STEM performanslarını öğrenebilmek amacıyla üç "Etkinlik Kâğıdı" uygulama sürecinde öğrencilere uygulanmıştır. Araştırma toplam altı hafta sürmüştür.

\subsubsection{Uygulama Takvimi ve Ders Plan1}

Araştırmacı tarafindan konular altı kazanıma göre işlenmiştir. Yapılan uygulama takvimi Tablo 3'te ve uygulama süreci Tablo 4'te verilmiştir.

Tablo 3. Uygulama Takvimi

\begin{tabular}{|c|c|c|c|}
\hline Zaman & Kazanım ve Testler & STEM Etkinlikleri & $\begin{array}{l}\text { Uygulama } \\
\text { ve Süre }\end{array}$ \\
\hline 1.HAFTA & $\begin{array}{l}\text { Ön test ( BSB) uygulanmış ve } \\
\text { uygulama öncesi öğrenciler } \\
\text { bilgilendirilmiştir. }\end{array}$ & & 4 Ders Saati \\
\hline $\begin{array}{l}2 \text { VE } 3 . \\
\text { HAFTA }\end{array}$ & Ön Etkinlik & Güneş Firını & $\begin{array}{l}8 \text { Ders Saati } \\
\text { Öğrencilere } \\
\text { Etkinlik } \\
\text { Kâğıdı } 1 \\
\text { verilmiştir. }\end{array}$ \\
\hline 4.HAFTA & $\begin{array}{l}\text { Kazanım6.3.1.1. Bir cisme } \\
\text { etki eden kuvvetin yönünü, } \\
\text { doğrultusunu ve büyüklüğ̈ünü } \\
\text { çizerek gösterir. } \\
\text { Kazanım6.3.1.2. Bir cisme } \\
\text { etki eden birden fazla kuvveti } \\
\text { deneyerek gözlemler. }\end{array}$ & Uçak Tasarımları Yarı̧̧ıor & $\begin{array}{l}4 \text { Ders Saati } \\
\text { Öğrencilere } \\
\text { Etkinlik } \\
\text { Kâğı̆dı } 2 \\
\text { verilmiştir }\end{array}$ \\
\hline 5.HAFTA & $\begin{array}{l}\text { Kazanım6.3.1.3. } \\
\text { Dengelenmiş ve } \\
\text { dengelenmemiş kuvvetleri, } \\
\text { cisimlerin hareket durumlarını } \\
\text { gözlemleyerek karşılaştırır. }\end{array}$ & $\begin{array}{l}\text { Gemi Batıyor } \mathrm{Mu} \text {, Yüzüyor } \\
\text { Mu? }\end{array}$ & $\begin{array}{l}4 \text { Ders Saati } \\
\text { Öğrencilere } \\
\text { Etkinlik } \\
\text { Kâğğdı } \\
\text { verilmiştir }\end{array}$ \\
\hline 6.HAFTA & $\begin{array}{l}\text { Kazanım.6.3.2.1. Sürati } \\
\text { tanımlar ve birimini ifade eder. } \\
\text { Kazanım6.3.2.2. Yol, zaman } \\
\text { ve sürat arasındaki ilişkiyi } \\
\text { grafik üzerinde gösterir. } \\
\text { Kazanım6.3.2.3. Bileşke } \\
\text { Kuvvet ve Sabit Süratli } \\
\text { Hareket ile ilgili çalısmalar } \\
\text { yapar } \\
\text { Son test (BSB) uygulanmıstır. }\end{array}$ & F1 Yarışı Başlasın! & $\begin{array}{l}4 \text { Ders Saati } \\
\text { Öğrencilere } \\
\text { Etkinlik } \\
\text { Kâğıdı } \\
\text { verilmiştir }\end{array}$ \\
\hline
\end{tabular}


Tablo 4. Uygulama Süreci

\begin{tabular}{|c|c|}
\hline 5E MODELİ & STEM ETKİNLİKLERİNİN UYGULANMA SÜRECİ \\
\hline GİRİŞ & $\begin{array}{l}\text { Bu aşamada konuya dikkat çekebilmek amacıyla senaryo dâhilinde hazırlanan } \\
\text { karikatür akıllı tahtada öğrencilere gösterilir. Ardından karikatürde verilen soruna } \\
\text { çözüm üretilebilmesi için mühendislik görevi dâhinde problemin farkına varılması } \\
\text { sağlanarak problemi tanımlamaları istenir. Problemi tanımlayan mühendislik } \\
\text { rolündeki öğrencilerin, mühendislik görevleri için verilen birinci yönerge: "Tersanede } \\
\text { çalışan yeni gemi mühendisleri sizsiniz. Soruna çözüm getirebilecek sınırlılıklar } \\
\text { dâhilinde en iyi çözüm için nasıl bir tasarım yapılmalıdır? Maddeler halinde } \\
\text { yazınız."dır. Bu yönerge, öğrencileri probleme yönelik çözüm önerileri geliştirmeleri } \\
\text { doğrultusunda yönlendirmelidir. }\end{array}$ \\
\hline KEŞFETME & $\begin{array}{l}\text { Bu aşamada öğrenciler, üretilen çözüm önerileri grup içinde tartışlarak problemin } \\
\text { çözümüne uygun en iyi tasarımın hangisi seçileceğine dair fikir alışıverişinde } \\
\text { bulunulur. En iyi çözüm önerisi seçilip sistemin tasarımına ilişkin çizim ve } \\
\text { hesaplamaların yapılması istenir. Bu mühendislik görevi için ikinci yönerge: " } \\
\text { Arkadaşlarınızla çözüm önerilerinizi düşünüp tartışarak en uygun çözüm önerinizi } \\
\text { belirleyin. Tasarladığını gemilerin çalı̧ma prensiplerini açılayan bir çizim yapın. } \\
\text { Çizim sonrası kullanılacak malzemeleri grupça temin ediniz. " yöneltilir. Öğrenciler, } \\
\text { öncelikle çizdikleri çözüm önerisi için verilen kriterleri göz önüne alarak } \\
\text { tasarımlarında ne tür malzemeler kullanabilecekleri, bu malzemelerin alternatiflerini } \\
\text { ve hangi amaçla kullanabileceklerini etkinlik kâğıdındaki tabloya yazarlar. Daha sonnra } \\
\text { kendilerine sunulan malzemelerden verilen kriterler göz önüne alarak seçerler. } \\
\text { Üçüncü yönergede ise tasarımı yapımında dikkat edilecek matematiksel } \\
\text { hesaplamaların yapılması gerektiği hatırlatılarak farklı disiplinlerin nerede, nasıl ve ne } \\
\text { amaçla kullanıldığına farkına varmaları sağlanır. Daha sonra çizimi yapılan sistemin } \\
\text { tasarımına geçilmesi için dördüncü yönergede: " Sevgili mühendislerimiz tasarımını } \\
\text { yaptığınız sistemi inşa etmeye hazır olun" yöneltilerek öğrencilerin tasarım aşamasına } \\
\text { geçmeleri sağlanır. Tasarım test edilirken tasarımın deneme aşamaları kaydedilmesi } \\
\text { sağlanır. Denenen tasarıma ait değiskenlerin belirlenmesi sağlanır ve öğrencilerden } \\
\text { tasarım sonucunda ne olmasını beklediklerini etkinlik kâğıdına yazmaları istenir. } \\
\text { Deney sonrası elde edilen bulgular (tasarımın özellikleri, hız, yol ve zaman) tabloya } \\
\text { kaydedilmesi sağlanır ve elde edilen bulgular doğrultusunda her grubun grafik çizmesi } \\
\text { istenir. Sonucunda en başarılı takım seçilir. }\end{array}$ \\
\hline AÇIKLAMA & $\begin{array}{l}\text { Bu aşamada öğrencilere, yere hiç düşmeden giden en fazla yük taşıyan gemi } \\
\text { tasarlanabilmesi için gerekli olan "Kuvvet ve Hareket" konusuna dair bilgiler verilir. } \\
\text { En başarılı seçilen takımın gemisinin neden diğerlerinden daha fazla yük taşıyabildiği } \\
\text { ve batmadan yüzebildiği açılklanır. }\end{array}$ \\
\hline DERİNLEŞTİRME & $\begin{array}{l}\text { Bu aşamada öğrenciler, kendi tasarımlarıyla diğer takımların tasarımlarını inceleyip } \\
\text { tasarımlarının güçlü ve zayıf yönlerini belirlemeleri istenir. Bu saptamalar } \\
\text { doğrultusunda yeni bir tasarım inşa etmeleri istenir. }\end{array}$ \\
\hline DEĞERLENDİRME & $\begin{array}{l}\text { Bu aşamada öğrenciler, STEM etkinlikleri ile desteklenmiş fen öğretimi sonucunda } \\
\text { Öz değerlendirmelerini yapmaları için Öz Değerlendirme Rubriği uygulanır. }\end{array}$ \\
\hline
\end{tabular}

\subsection{Verilerin Analizi}

Araştırmada bilimsel süreç becerileri testinden elde edilen nicel veriler bir istatistik programı ile analiz edilmiştir. Öncelikle BSB'nin ön test ve son test puanlarının Kolmogorov- Smirnov testi yardımıyla normal dağılımı incelenmiştir. BSB ön test ve son test sonuçlarının normal dağıldığı görülmüş̧ür ( $\left.\mathrm{p}_{\text {ön }}=.214>.05 ; \mathrm{p}_{\mathrm{son}}=.523>.05\right) . \mathrm{Bu}$ nedenle parametrik testlerden ilişkili $\mathrm{t}$ testi kullanılmıştır. Normal dağılımın görüldüğü ve örneklemin 30'u geçtiği çalışmalarda parametrik testler kullanilır (Can, 2018).

Araştırmanın nitel boyutu için etkinlik kâğıtlarından veriler elde edilmiştir. Uygulama sürecinde yapılan her bir etkinlik için etkinlik kâğıdı öğrencilere boş form olarak verilmiş ve her etkinliğin sonunda gruplar tarafından doldurulan etkinlik kâğıtları toplanmıştır. Her grup her etkinlik için bir tane etkinlik kâğıdı doldurmuş ve sürecin sonunda her gruptan üç etkinlik kâğıdı toplanmıştır.

Etkinlik kâğıtlarını değerlendirmek için Sürmeli, Yıldırım, Göcük ve Sevgi (2018) tarafından geliştirilen rubrik ve bilimsel süreç becerileri temel alınarak belirlenen STEM performansları 
Köngül, Ö., \& Yıldırım, M. (2021). Title in article's language. Journal of Human Sciences, 18(2), 159-184. doi: $10.14687 /$ jhs.v18i2.6066

araştırmacılar tarafindan hazırlanan üç (çok, orta ve az) dereceli rubriğe göre puanlanmıştır. Grupların performans derecesi iyi ise (3) puan, orta ise (2) puan, iyi değilse (1) puan almışlardır. STEM performans puanlaması yaparken her bölüme uygun belirli anahtar kelimeler belirlenmiş ve grupların cevaplarında bulunmasına göre puanlama yapılmıştır. Grupların her etkinlikte performans değeri toplam puanlar ile belirlenmiştir. Bu puanlamalar dikkate alınarak grafikler oluşturulmuş ve yorumlanmıştr.

Rubrikten alınabilecek en düşük puan 15 olurken en yüksek puan 45’tir. Geliştirilen rubriğin puan grupları Tablo 5'de sunulmuştur

Tablo 5. STEM Performans Rubriği Puan Aralıkları ve Düzeyleri

\begin{tabular}{llll}
\hline & Az & Orta & Çok \\
\hline 3'lü puanlama anahtar1 & $15-24$ & $25-35$ & $35-45$ \\
\hline
\end{tabular}

\section{Bulgular \\ 3.1. STEM Uygulamaları ile Desteklenmiş Fen Öğretiminin Ortaokul Öğrencilerinin Bilimsel Süreç Becerilerinin Gelişimine İlişkin Bulgular}

Çalışma grubuna uygulama öncesi yapılan ön test, uygulama sonrası yapılan son test arasındaki fark ilişkili gruplar t- testi ile değerlendirilmiştir.

Tablo 6. Çalışma grubunun bilimsel süreç becerileri testi ön test ve son test puanları arasındaki farkla ilgili ilişkili örneklemler " $\mathrm{t}$ " testi sonuçları

\begin{tabular}{llllllll}
\hline Grup & Testler & $\mathbf{N}$ & $\overline{\boldsymbol{x}}$ & $\mathbf{S}$ & $\mathbf{s d}$ & $\mathbf{t}$ & $\mathbf{p}$ \\
\hline Çalışma grubu & Ön test & 35 & 12,8 & 3,4 & 34 & $-7,854$ & 0,00 \\
& Son test & 35 & 16,0 & 2,8 & & & \\
\hline
\end{tabular}

Tablo 6'da çalışma grubu öğrencilerinin Bilimsel Süreç Becerileri Testi ön test ve son testinden elde edilen bulgular incelendiğinde; çalışma grubu öğrencilerinin ön test ortalaması 12,8 iken son testlerinin ortalaması 16,0 olduğu anlaşılmaktadır. Ön test ve son test puanlarının ortalaması arasındaki fark 3,2 olduğu görülmektedir. Anlamlılık seviyesi $\mathrm{p}$ değerinin $\mathrm{p}<0,05$ olduğu görülmektedir. Bu bulgulara göre son test ile ön testler arasında son test lehine anlamlı bir farklillk bulunmuştur.

\section{2. Öğrencilerin STEM Uygulamalarını Gerçekleştirme Performanslarına Ait Bulgular}

Öğrencilerin STEM uygulamalarını gerçekleştirme performanslarına ilişkin bulgular tüm süreçte yapılan etkinliklere yönelik gruplar tarafindan doldurulan etkinlik kâğıtlarından elde edilmiştir. Kazanımlara göre her bir grubun üç etkinlik ile ilgili performanslarına ait bulgular Tablo 7'de verilmiştir. Tablo incelendiğinde 44 puan en yüksek alınan performans puanıdır ve ikinci grup üçüncü etkinlikte bu puanı almıştır. En düşük performans puanı 29 dur ve birinci grubun ikinci etkinlikteki puanıdır. Bir, iki ve beşinci grubun tüm etkinlik performansları açısından üçüncü etkinlik performanslarının en iyi olduğu, üç ve altıncı grubun ikinci etkinlikte en iyi performansı gösterdiği ve dördüncü grubun ise birinci etkinlikte en iyi performansa sahip olduğu görülmektedir. En düşük performanslarına bakıldığında bir, iki, dört ve beşinci gruplar en kötü performanslarını ikinci etkinlikte gerçekleştirmişlerdir. Üç ve altıncı grup birinci etkinlikte ve yine üçüncü grup üçüncü etkinlikte düşük performans puanı almışlardır. Bu tablodan rubriğe göre alınacak en yüksek puan 45 , en düşük puan ise 15 'dir, tabloda alınan en düşük puanın 29, en yüksek puanın ise 44 olduğu görülmektedir. 
Köngül, Ö., \& Yıldırım, M. (2021). Title in article's language. Journal of Human Sciences, 18(2), 159-184. doi:10.14687/jhs.v18i2.6066

Tablo 7. Çalışma Grubu Öğrencilerinin Etkinlik Kâğıtlarındaki Performanslarına Göre Frekans

Dağılimı

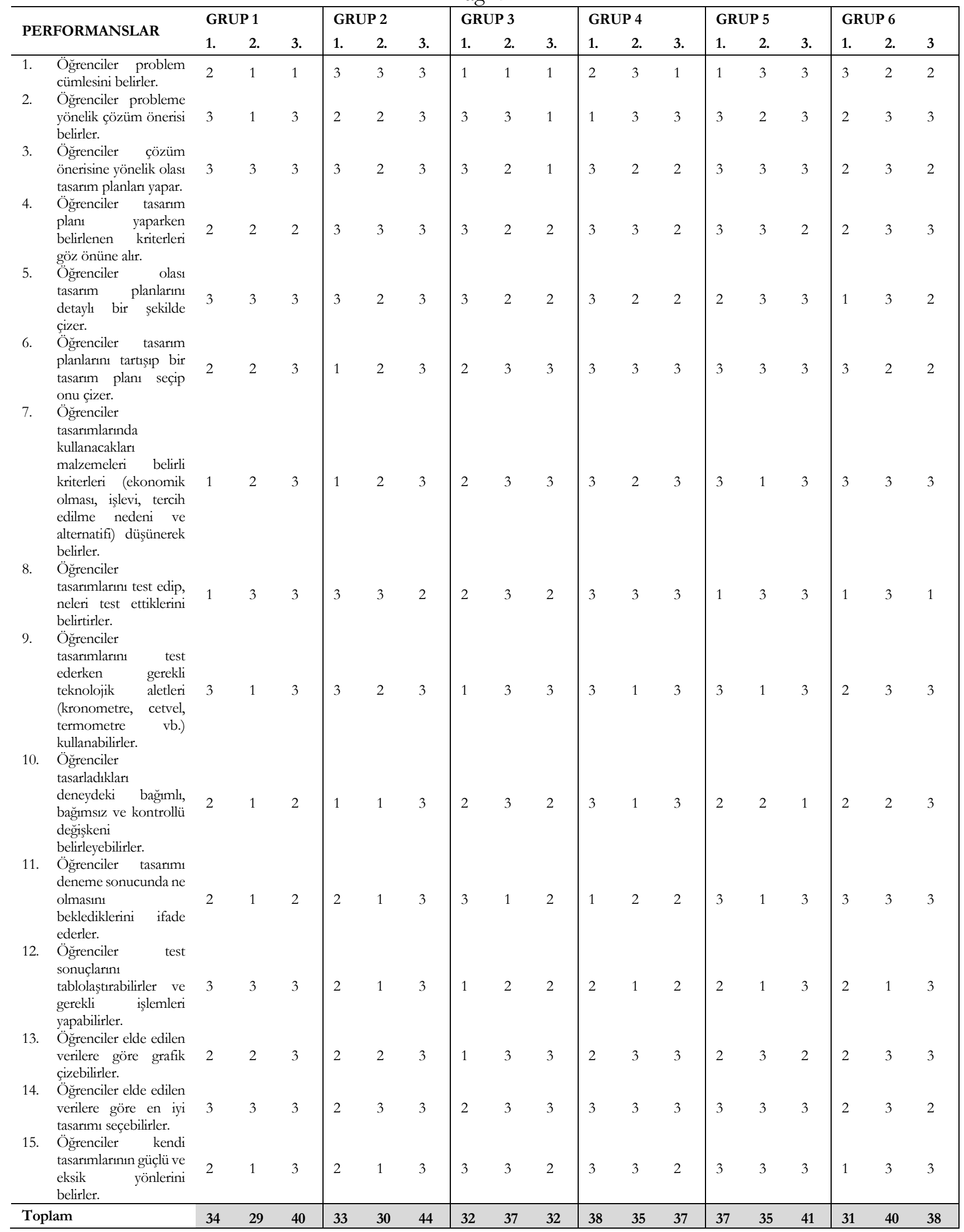


Köngül, Ö., \& Yıldırım, M. (2021). Title in article's language. Journal of Human Sciences, 18(2), 159-184. doi:10.14687/jhs.v18i2.6066

\subsubsection{Madde 1. "Öğrenciler problem cümlesini belirler." Performansına İlişkin Bulgular}

Birinci madde ile ilgili frekans değerleri Grafik 1'de verilmiştir.
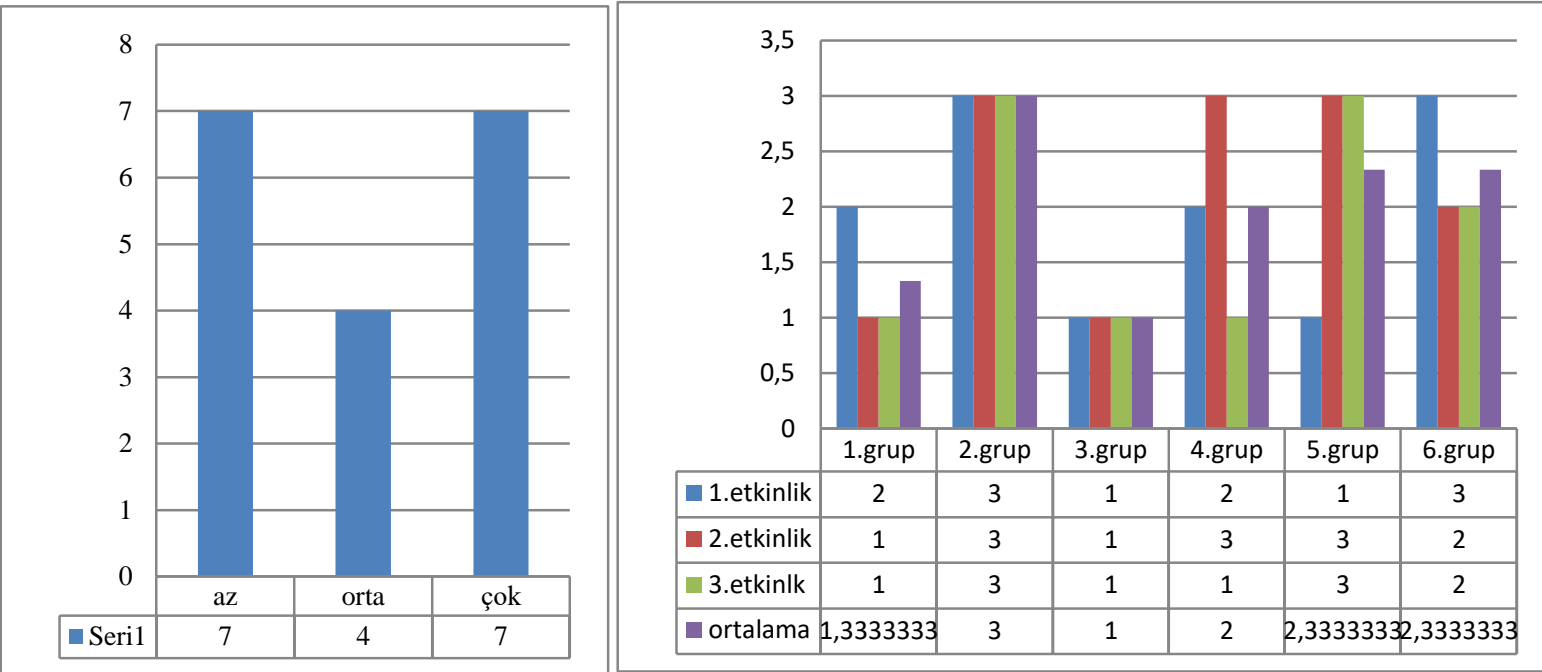

Grafik 1. 1. Performansın Frekansları Grafik 2. Grupların 1. Performansı Başarabilme Derecesi Her bir performans bir grup için üç kere (üç etkinlik) ve altı grup olduğundan dolayı on sekiz kez gruplar belirli performans için ölçülmüştür.

Altı gruba yapılan üç farklı etkinlik için (toplam $18 \mathrm{kez}$ ) birinci performans frekansına bakıldığında sinıfta yedi grup az derecede, dört grup orta derecede ve yedi grup yüksek derecede problem cümlesini belirleyebildiği görülmüştür.

Altı grubun her üç etkinlik için problem cümlesi belirleyebilme derecesi Grafik 2'de verilmiştir. Az derece için 1 puan, orta derece için 2 puan ve çok derecesi için 3 puan verilmiştir.

Birinci grubun birinci etkinlikte problem cümlesi belirme düzeyi orta dereceyken ikinci ve üçüncü etkinliklerde az düzeyde olmuştur. İkinci grubun üç etkinlikte de problem cümlesi belirleme düzeyi çok derecesindedir. Üçüncü grup üç etkinlikte de problem belirleme derecesi az düzeyde olmuştur. Dördüncü grup birinci etkinlikte orta, ikinci etkinlikte çok ve üçüncü etkinlikte az düzeyde problem cümlesi belirleme derecesindedir. Beşinci grup, birinci etkinlikte az, ikinci ve üçüncü etkinliklerde çok derecede problem cümlesi belirleme düzeyindedir. Altıncı grup, birinci etkinlikte çok, ikinci ve üçüncü etkinliklerde çok derecede problem cümlesi belirleme düzeyine sahiptir.

3.2.2. Madde 2. "Öğrenciler probleme yönelik çözüm önerisi belirler." Performansına İlişkin Bulgular

İkinci madde ile ilgili frekans değerleri Grafik 3 ve 4'te verilmiştir.
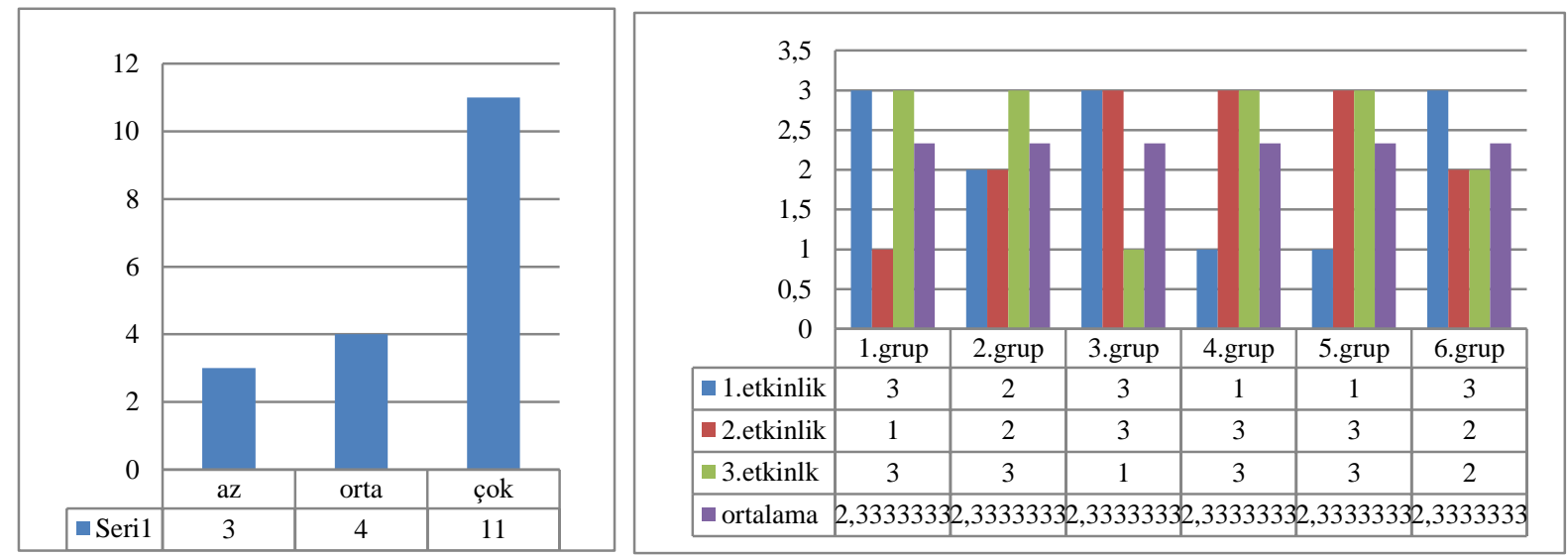

Grafik 3. İkinci Performansın Frekansları Grafik 4. Grupların İkinci Performansı Başarabilme Derecesi 
Köngül, Ö., \& Yıldırım, M. (2021). Title in article's language. Journal of Human Sciences, 18(2), 159-184. doi:10.14687/jhs.v18i2.6066

Alı gruba yapılan üç farklı etkinlik için (toplam 18 kez) ikinci performans frekansına bakıldığında sınıftaki üç grubun az derecede, dört grubun orta derecede ve on bir grubun yüksek derecede probleme çözüm önerisi belirleyebildiği görülmüştür.

Birinci grubun birinci etkinlikte probleme çözüm önerisi belirleyebilme derecesi çok, ikinci etkinlikte çok ve üçüncü etkinlikte tekrar çok derecesindedir. İkinci grubun, birinci ve ikinci etkinlikte probleme çözüm önerisi belirleyebilme derecesi ortayken üçüncü etkinlikte çok olmuştur. Üçüncü grubun birinci ve ikinci etkinlikte çok, üçüncü etkinlikte az derecede probleme çözüm önerisi belirleyebilme düzeyinde olmuştur. Dördüncü grubun, birinci etkinlikte probleme çözüm önerisi belirleyebilme derecesi az, ikinci ve üçüncü etkinliklerde çok derecededir. Beşinci grubun, birinci etkinlikte probleme çözüm önerisi belirleyebilme derecesi az, ikinci ve üçüncü etkinliklerde çok derecededir. Altnncı grubun birinci etkinlikte çok derecede, ikinci ve üçüncü etkinlikte orta derecede probleme çözüm önerisi olmuştur.

3.2.3. Madde 3. "Öğrenciler çözüm önerisine yönelik olası tasarım planları yapar." Performansına İlişkin Bulgular

Üçüncü madde ile ilgili frekans değerleri Grafik 5 ve 6'da verilmiştir.
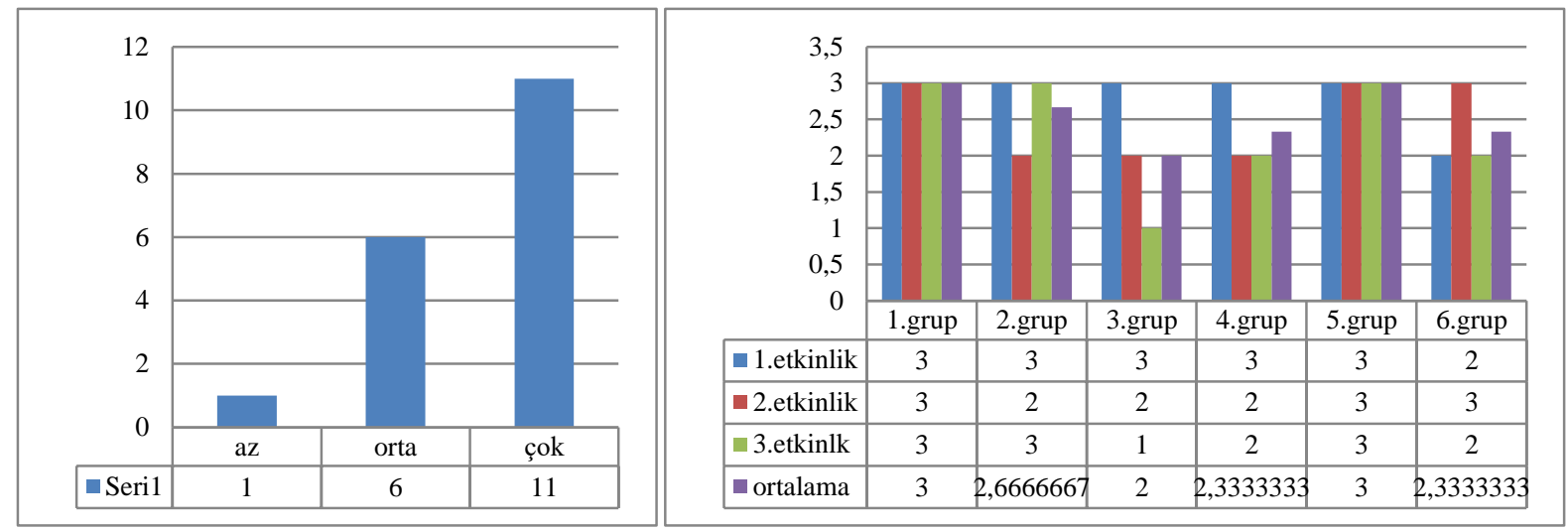

Grafik 5. 3.Performans Frekansları Grafik 6. Grupların Üçüncü Performansı Başarabilme Derecesi

Altı gruba yapılan üç farklı etkinlik için (toplam 18 kez) üçüncü performans frekansına bakıldığında sınıftaki bir grup az derecede, altı grup orta derecede ve on bir grup yüksek derecede probleme yönelik olası tasarım planları yapabildiği görülmüştür.

Birinci grubun tasarım planı yapabilme derecesi üç etkinlikte de yüksek düzeydedir. İkinci grubun, birinci etkinlikte tasarım planı yapabilme düzeyi çok, ikinci etkinlikte orta ve üçüncü etkinlikte çok derecededir. Üçüncü grubun, tasarım planı yapabilme düzeyi birinci etkinlikte çok, ikinci etkinlikte orta ve üçüncü etkinlikte ise az derecededir. Dördüncü grubun, birinci etkinlikte çok, ikinci ve üçüncü etkinlikte orta derecede tasarım planı yapabilmektedir. Beşinci grup, her üç etkinlikte de yüksek derecede tasarım planı yapabilmektedir. Altnncı grup, birinci etkinlikte orta, ikinci etkinlikte çok ve üçüncü etkinlikte orta derecede tasarım planı yapabilmektedir 
Köngül, Ö., \& Yıldırım, M. (2021). Title in article's language. Journal of Human Sciences, 18(2), 159-184. doi:10.14687/jhs.v18i2.6066

\subsubsection{Madde 4. "Öğrenciler tasarım planı yaparken belirlenen kriterleri göz önüne alır." Performansına İlişkin Bulgular}

Dördüncü madde ile ilgili frekans değerleri Grafik 7'de verilmiştir.
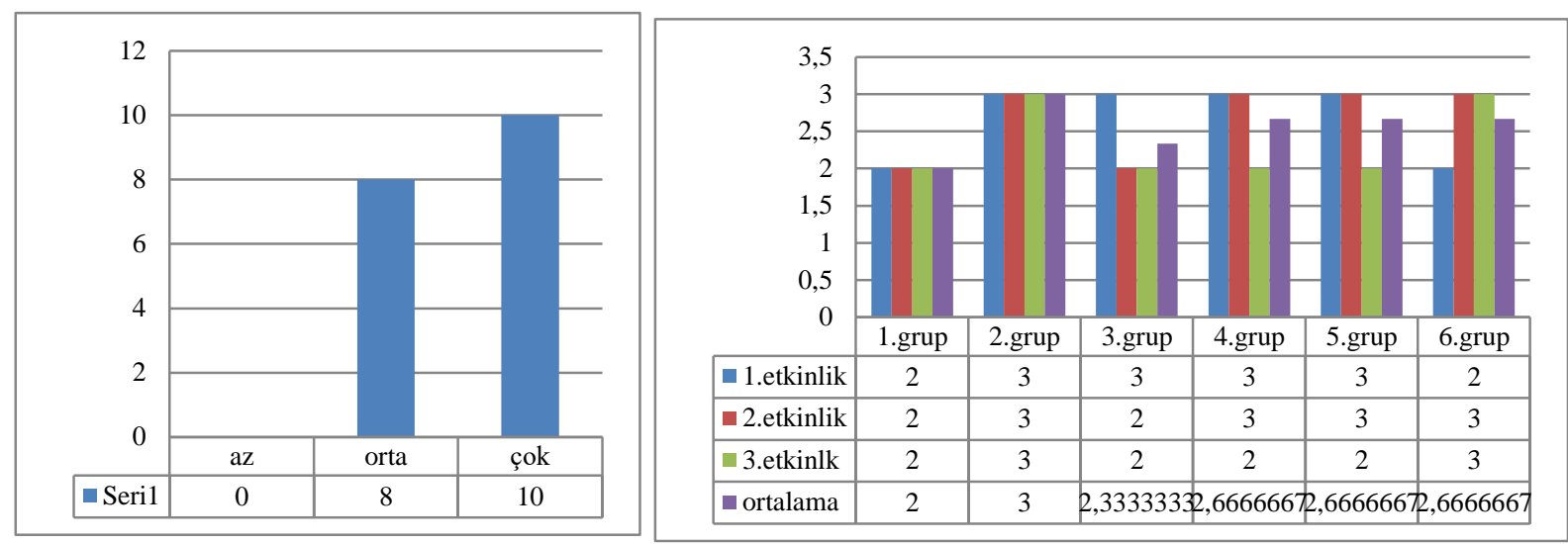

Grafik 7. 4. Performansın Frekansları Grafik 8. Grupların 4. Performansı Başarabilme Derecesi

Altı gruba yapılan üç farklı etkinlik için (toplam 18 kez) dördüncü performans frekansına bakıldığında sinıftaki sekiz grup orta derecede ve on grup yüksek derecede tasarım planı yaparken kriterleri göz önüne alabildiği görülmüştür.

Birinci grubun, tasarım yaparken kriterleri göz önüne alma derecesi üç etkinlik için de orta düzeyde olmuştur. İkinci grubun, kriterleri göz önüne alma derecesi üç etkinlik için de yüksek derecede olmuştur. Üçüncü grup, birinci etkinlikte yüksek, ikinci ve üçüncü etkinlikte orta düzeyde tasarım yaparken kriterleri göz önüne almıştır. Dördüncü grup, birinci ve ikinci etkinlikte yüksek, üçüncü etkinlikte orta derecede kriterleri göz önüne almıştr. Beşinci grup, bir ve ikinci etkinlikte yüksek derecede kriterleri göz önüne almış ancak üçüncü etkinlikte orta derecededir. Altnncı grup, birinci etkinlikte orta düzeyde, ikinci ve üçüncü etkinlikte yüksek derecede tasarım yaparken kriterleri göz önüne almıştır.

\subsubsection{Madde 5. "Öğrenciler olası tasarım planlanını detaylı bir şekilde çizer." Performansına İlişkin Bulgular}

Beşinci madde ile ilgili frekans değerleri Grafik 9 ve 10 'da verilmiştir. Altı gruba yapılan üç farklı etkinlik için (toplam $18 \mathrm{kez}$ ) beşinci performans frekansına bakıldığında sınıftaki bir grup az derecede, yedi grup orta derecede ve on grup yüksek derecede probleme yönelik tasarım planlarını detaylı çizebildikleri görülmüştür.
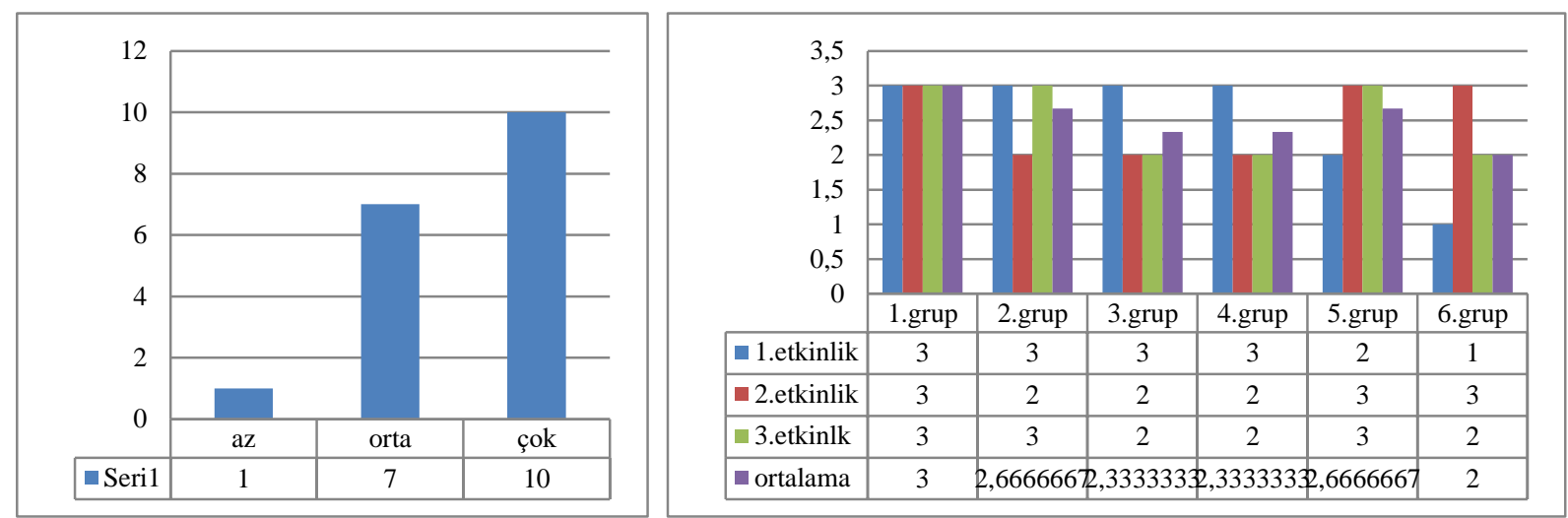

Grafik 9. 5. Performansın Frekansları Grafik 10. Grupların 5.Performansı Başarabilme Derecesi 
Köngül, Ö., \& Yıldırım, M. (2021). Title in article's language. Journal of Human Sciences, 18(2), 159-184. doi:10.14687/jhs.v18i2.6066

Birinci grup, tasarımlarını detaylı çizmede üç etkinlikte de yüksek derecededir. İkinci grup, birinci etkinlikte yüksek, ikinci etkinlikte orta ve üçüncü etkinlikte yüksek derecede tasarım planlarını detaylı çizebilmiştir. Üçüncü grup, birinci etkinlikte yüksek, ikinci ve üçüncü etkinlikte orta derecede tasarım planlarını çizebilmiştir. Dördüncü grup, birinci etkinlikte yüksek, ikinci ve üçüncü etkinlikte orta derecede tasarım planlarını çizebilmiştir. Beşinci grup, tasarım planlarını çizebilmekte birinci etkinlikte orta, ikinci ve üçüncü etkinlikte yüksek derecededir. Altıncı grup, birinci etkinlikte az, ikinci etkinlikte yüksek ve üçüncü etkinlikte orta düzeyde tasarımlarını detaylı çizebilmiştir.

3.2.6. Madde 6. "Öğrenciler tasarım planlarını tartışıp bir tasarım planı seçip onu çizer." Performansına İlişkin Bulgular

Altnncı madde ile ilgili frekans değerleri Grafik 11 ve 12 'de verilmiştir. Altı gruba yapılan üç farklı etkinlik için (toplam $18 \mathrm{kez}$ ) altıncı performans frekansına bakıldığında sınıftaki iki grup az derecede, altı grup orta derecede ve on bir grup yüksek derecede tasarım planı seçip çizebildiği
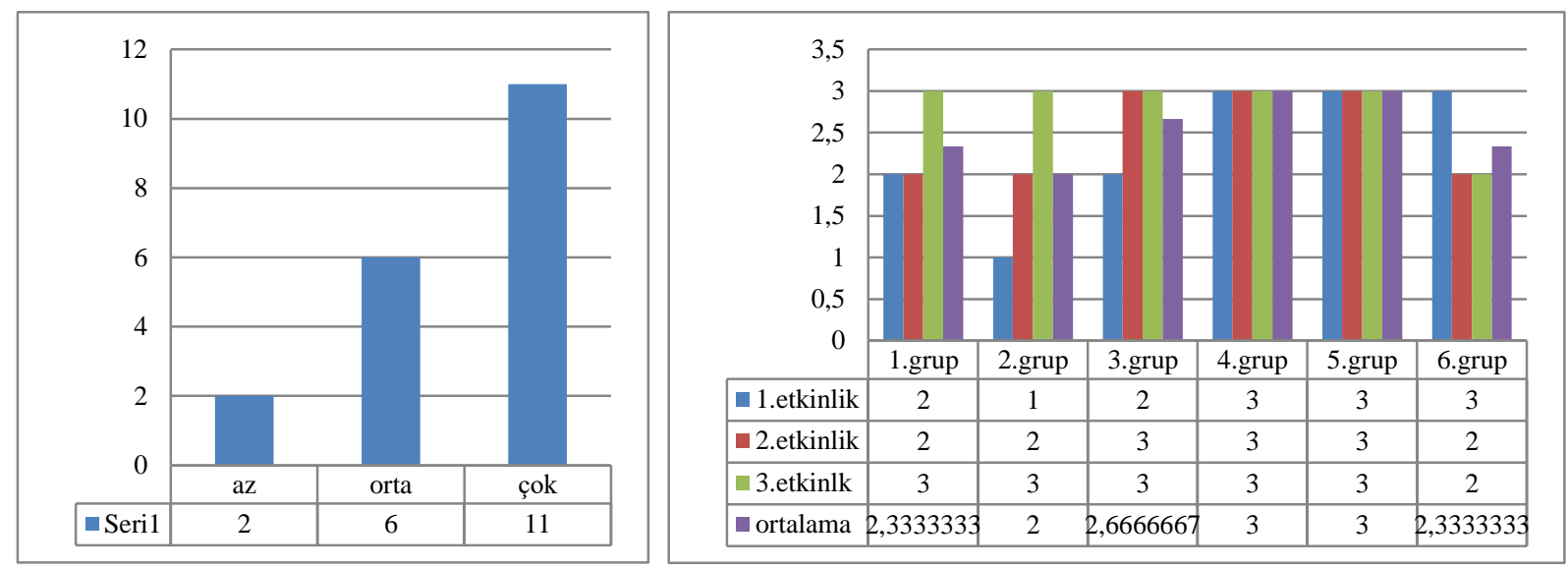

görülmüştür.

Grafik 11. 6. Performansın Frekanslanı Grafik 12. Grupların 6. Performansı Başarabilme Derecesi

Birinci grup, tasarım planı seçip onu çizmede bir ve ikinci etkinlikte orta derecede, üçüncü etkinlikte yüksek derecededir. İkinci grup, birinci etkinlikte az, ikinci etkinlikte orta, üçüncü etkinlikte yüksek derecede tasarım planı seçip onu çizmiştir. Üçüncü grup, birinci etkinlikte orta, iki ve üçüncü etkinlikte yüksek derecede tasarım planı seçip onu çizmiştir. Dördüncü grup ve beşinci grup üç etkinlikte de yüksek derecede tasarım planı seçip, çizebilmiştir. Altıncı grup, birinci etkinlikte çok, ikinci ve üçüncü etkinliklerde orta derecede tasarım planı seçip çizebilmiştir.

3.2.7. Madde 7. "Öğrenciler tasarımlarında kullanacakları malzemeleri belirli kriterleri (ekonomik olması, işlevi, tercih edilme nedeni ve alternatifi) düşünerek belirler." Performansına İlişkin Bulgular

Yedinci madde ile ilgili frekans değerleri Grafik 13 ve 14 'te verilmiştir
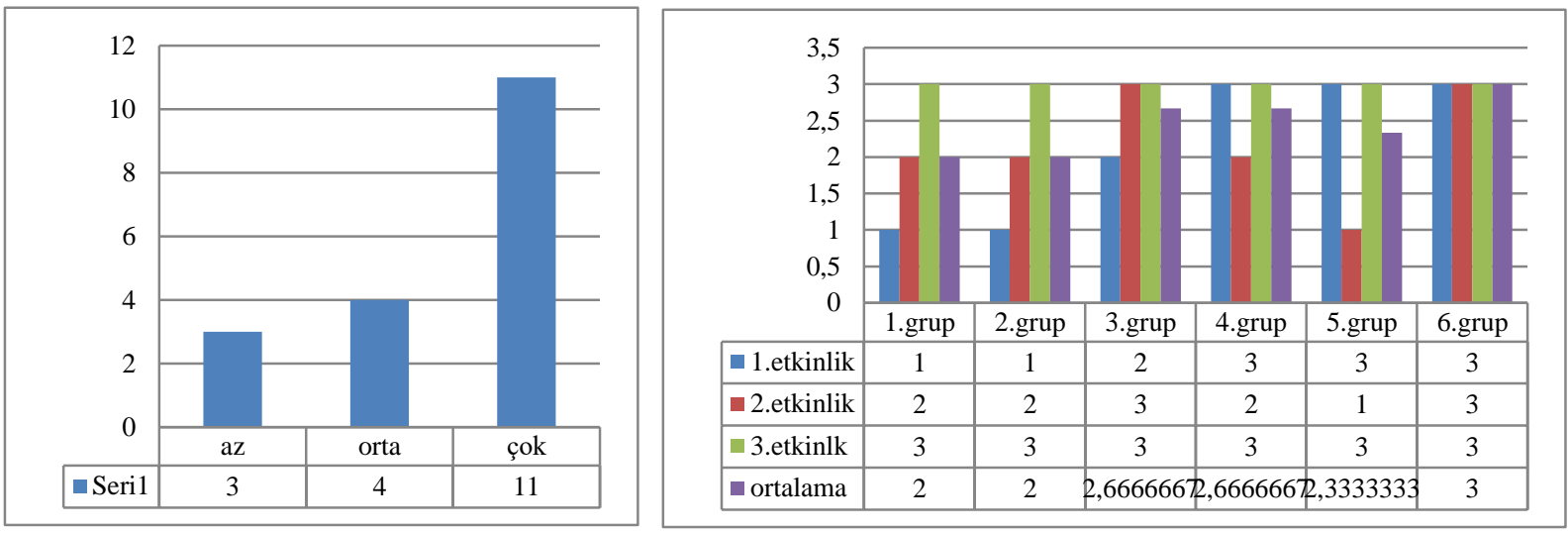
Köngül, Ö., \& Yıldırım, M. (2021). Title in article's language. Journal of Human Sciences, 18(2), 159-184. doi:10.14687/jhs.v18i2.6066

Grafik 13. 7. Performansın Frekansları Grafik 14. Grupların 7.Performansı Başarabilme Derecesi Altı gruba yapılan üç farklı etkinlik için (toplam $18 \mathrm{kez}$ ) yedinci performans frekansına bakıldığında sınıftaki üç grup az derecede, dört grup orta derecede ve on bir grup yüksek derecede malzemeleri belirlerken kriterleri göz önüne aldığı görülmüştür.

Birinci grup, malzeme seçerken kriterleri göz önüne almada birinci etkinlikte az, ikinci etkinlikte orta ve üçüncü etkinlikte yüksek derecededir. İkinci grup, birinci etkinlikte az, ikinci etkinlikte orta ve üçüncü etkinlikte yüksek derecede malzeme seçerken kriterleri göz önüne alır. Üçüncü grup, malzeme seçerken kriterleri göz önüne almada birinci etkinlikte orta, iki ve üçüncü etkinlikte yüksek derecededir. Dördüncü grup, bir ve üçüncü etkinlikte yüksek, ikinci etkinlikte orta derecede malzeme seçerken kriterleri göz önüne alır. Beşinci grup, malzeme seçerken kriterleri düşünmede bir ve üçüncü etkinlikte yüksek, ikinci etkinlikte az derecededir. Altıncı grup üç etkinlikte de yüksek derecede malzeme seçerken kriterleri göz önüne alır.

\subsubsection{Madde 8. "Öğrenciler tasarımlarını test edip, neleri test ettiklerini belirtirler." Performansına İlişkin Bulgular}

Sekizinci madde ile ilgili frekans değerleri Grafik 15 ve 16'da verilmiştir. Altı gruba yapılan üç farklı etkinlik için (toplam 18 kez) sekizinci performans frekansına bakıldığında sınıftaki dört grup az derecede, üç grup orta derecede ve on bir grup yüksek derecede tasarımlarını test edip, neleri test edebildiklerini belirleyebildiklerini görülmüş̧ür.
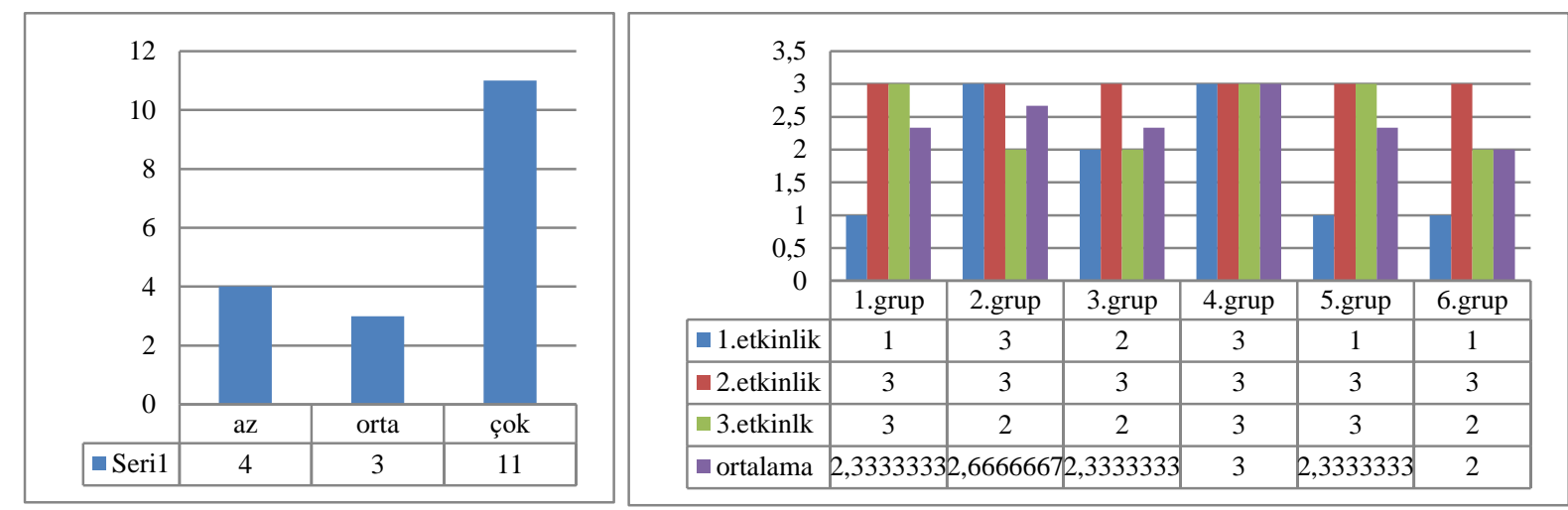

Grafik 15. 8. Performansın Frekansları Grafik 16. Grupların 8. Performansı Başarabilme Derecesi

Birinci grubun, tasarımı test edip, test edileni belirlemesi birinci etkinlikte az, iki ve üçüncü etkinlikte yüksek derecededir. İkinci grup, bir ve ikinci etkinlikte yüksek, üçüncü etkinlikte orta derecede test edilenleri belirlemiştir. Üçüncü grup, bir ve üçüncü etkinlikte orta, ikinci etkinlikte yüksek derecede test edilenleri belirlemiştir. Dördüncü grubun test edileni belirleme derecesi üç etkinlikte de yüksek derecededir. Beşinci grup, birinci etkinlikte az, iki ve üçüncü etkinlikte yüksek derecede test edilenleri belirler. Altınc1 grup test edileni belirlemesi birinci etkinlikte az, ikinci etkinlikte yüksek ve üçüncü etkinlikte orta derecededir. 
Köngül, Ö., \& Yıldırım, M. (2021). Title in article's language. Journal of Human Sciences, 18(2), 159-184. doi:10.14687/jhs.v18i2.6066

3.2.9. Madde 9. "Öğrenciler tasarımlarını test ederken gerekli teknolojik aletleri (kronometre, cetvel, termometre vb.) kullanabilirler." Performansına İlişkin Bulgular Dokuzuncu madde ile ilgili frekans değerleri Grafik 17 ve 18'de verilmiştir.
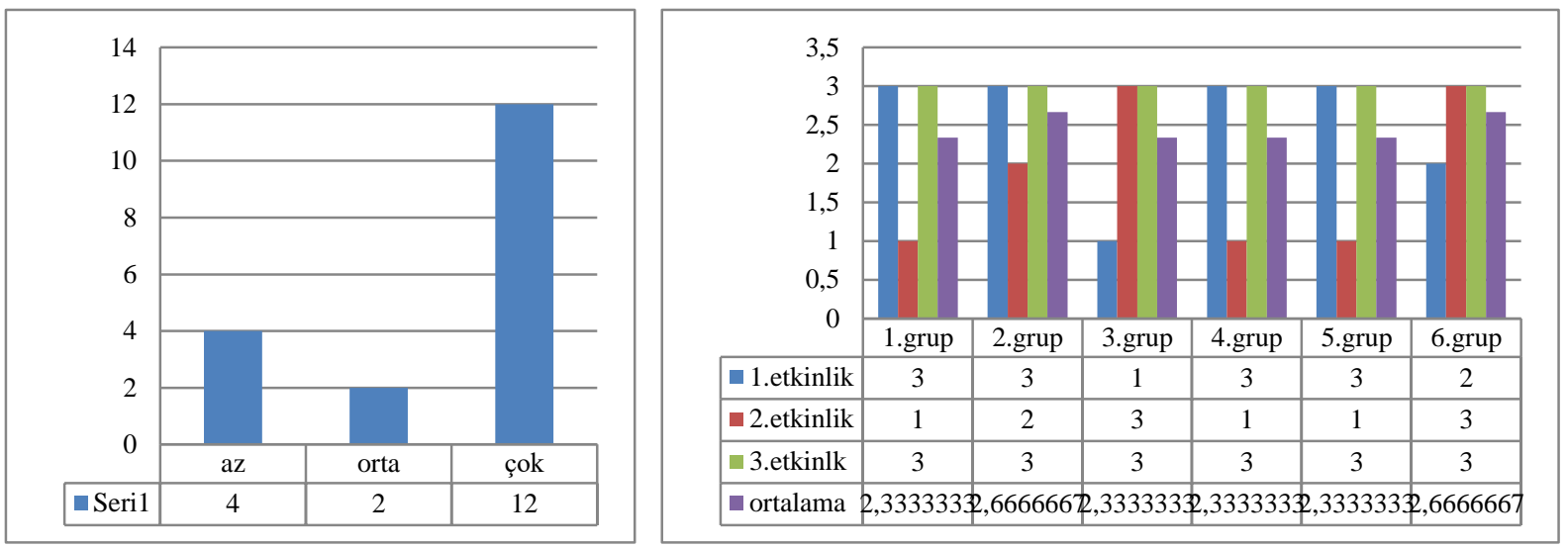

Grafik 17. 9. Performansın Frekansları Grafik 18. Grupların 9. Performansı Başarabilme Derecesi

Altı gruba yapılan üç farklı etkinlik için (toplam $18 \mathrm{kez}$ ) dokuzuncu performans frekansına bakıldığında sınıftaki dört grup az derecede, iki grup orta derecede ve on iki grup yüksek derecede tasarımlarını test ederken gerekli teknolojik aletleri kullanabildikleri görülmüştür.

Birinci grup, teknolojik aletleri kullanmada bir ve üçüncü etkinlikte yüksek, ikinci etkinlikte az derecededir. İkinci grup, bir ve üçüncü etkinlikte yüksek derecede, ikinci etkinlikte orta derecede teknolojik aletleri kullanabilmektedir. Üçüncü grup, birinci etkinlikte az, iki ve üçüncü etkinlikte yüksek derecede teknolojik aletleri kullanabilmektedir. Dördüncü ve beşinci grup, bir ve üçüncü etkinlikte yüksek, ikinci etkinlikte az derecede teknolojik alet kullanabilmektedir. Altuncı grup, teknolojik alet kullanmada birinci etkinlikte orta, iki ve üçüncü etkinlikte yüksek derecededir.

3.2.10. Madde 10." Öğrenciler tasarladıkları deneydeki bağımlı, bağımsız ve kontrollü değişkeni belirleyebilirler." Performansına İlişkin Bulgular

Onuncu madde ile ilgili frekans değerleri Grafik 19 ve 20'de verilmiştir.
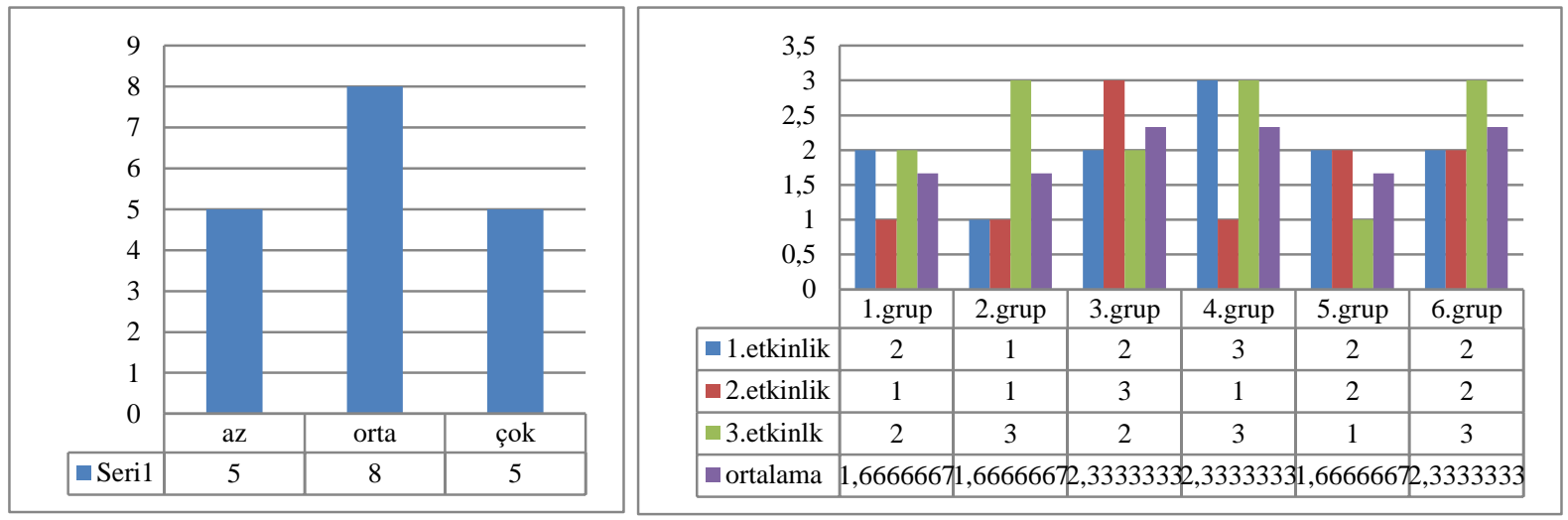

Grafik 19. 10. Performansın Frekansları Grafik 20. 10. Performansı Başarabilme Derecesi

Altı gruba yapılan üç farklı etkinlik için (toplam $18 \mathrm{kez}$ ) onuncu performans frekansına bakıldığında sinıftaki beş grup az derecede, sekiz grup orta derecede ve beş grup yüksek derecede değişkenleri belirleyebildiği görülmüştür.

Birinci grup, değişkenleri belirlemede bir ve üçüncü etkinlikte orta, ikinci etkinlikte az derecededir. İkinci grup, bir ve ikinci etkinlikte az derecede, üçüncü etkinlikte yüksek derecede değişkenleri belirlemişlerdir. Üçüncü grup, değişkenleri belirlemede bir ve üçüncü etkinlikte orta 
Köngül, Ö., \& Yıldırım, M. (2021). Title in article's language. Journal of Human Sciences, 18(2), 159-184. doi:10.14687/jhs.v18i2.6066

derecede, ikinci etkinlikte yüksek derecededir. Dördüncü grup, bir ve üçüncü etkinlikte değişkenleri yüksek derecede belirlemişler, ikinci etkinlikte az derecede belirlemişlerdir. Beşinci grup, bir ve ikinci etkinlikte orta, üçüncü etkinlikte az derecede değişkeleri belirlemişlerdir. Altıncı grup, bir ve ikinci etkinlikte orta derecede değişkenleri belirlemekte, üçüncü etkinlikte yüksek derecede belirlemişlerdir. 3.2.11. Madde 11. "Öğrenciler tasarımı deneme sonucunda ne olmasını beklediklerini ifade ederler." Performansına İlişkin Bulgular

On birinci madde ile ilgili frekans değerleri Grafik 21 ve 22'de verilmiştir. Altı gruba yapılan üç farklı etkinlik için (toplam $18 \mathrm{kez}$ ) on birinci performans frekansına bakıldığında sınıftaki beş grup az derecede, altı grup orta derecede ve yedi grup yüksek derecede tasarımı deneme sonucunda beklentilerini ifade edebildikleri görülmüştür.

Birinci grup tasarım sonucundaki beklentilerini ifade etmede bir ve üçüncü etkinlikte orta, ikinci etkinlikte az derecededir. İkinci grup birinci etkinlikte orta, ikinci etkinlikte az, üçüncü etkinlikte yüksek derecede tasarım sonucundaki beklentilerini ifade etmektedir. Üçüncü grup birinci etkinlikte tasarım sonucundaki beklentileri ifade etmede yüksek, ikinci etkinlikte az ve üçüncü etkinlikte orta derecededir.
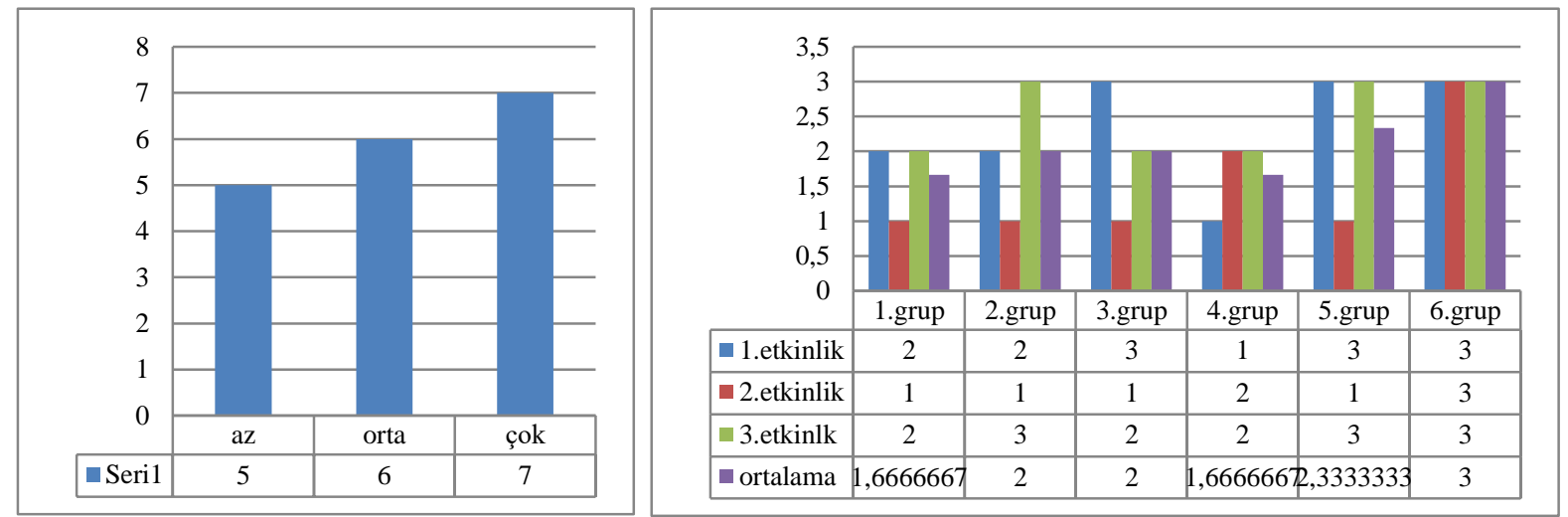

Grafik 21. 11. Performansın Frekanslanı Grafik 22. 11. Performansı Başarabilme Derecesi

Dördüncü grup birinci etkinlikte az, iki ve üçüncü etkinlikte yüksek derecede tasarım sonucunda beklentilerini ifade etmektedir. Beşinci grup, bir ve üçüncü etkinlikte yüksek, ikinci etkinlikte az derecede tasarım sonucundaki beklentilerini ifade eder. Altıncı grup, üç etkinlikte de yüksek derecede tasarım sonucundaki beklentilerini ifade eder.

3.2.12. Madde 12. "Öğrenciler test sonuçlarını tablolaştırabilirler ve gerekli işlemleri yapabilirler." Performansına İlişkin Bulgular

On ikinci madde ile ilgili frekans değerleri Grafik 23 ve 24 'te verilmiştir.
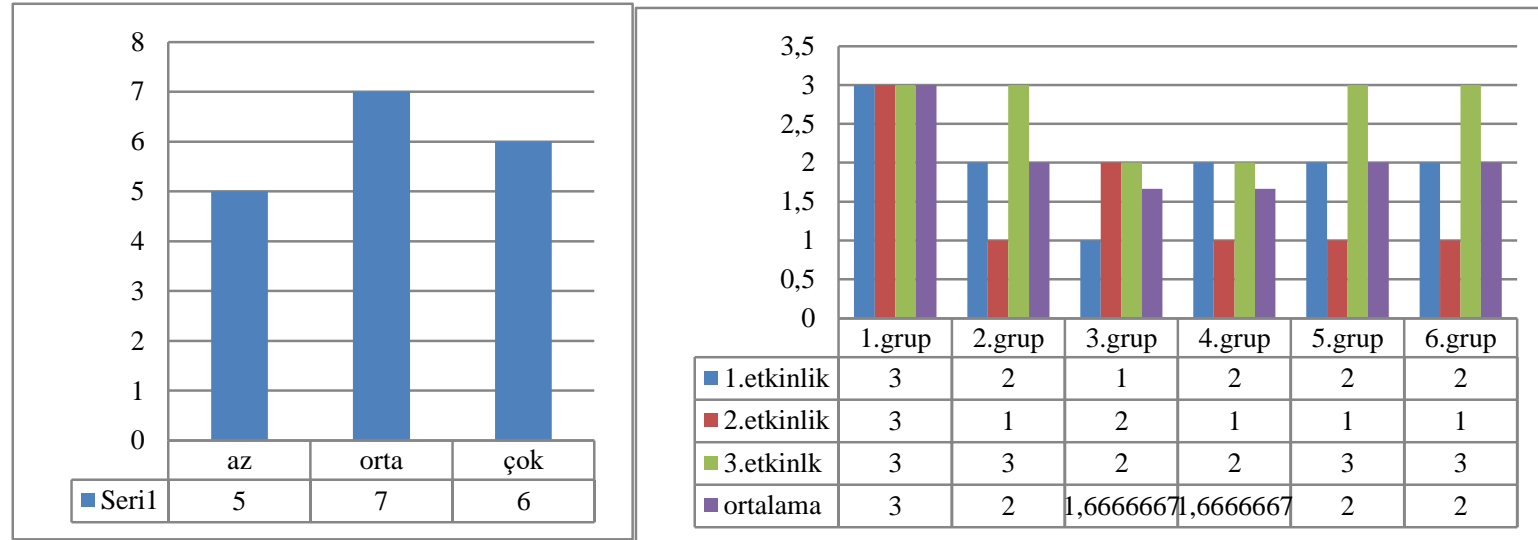

Grafik 23. 12. Performansın Frekansları Grafik 24. 12. Performansı Başarabilme Derecesi 
Köngül, Ö., \& Yildırım, M. (2021). Title in article's language. Journal of Human Sciences, 18(2), 159-184. doi:10.14687/jhs.v18i2.6066

Altı gruba yapılan üç farklı etkinlik için (toplam $18 \mathrm{kez}$ ) on ikinci performans frekansına bakıldığında sınıftaki beş grup az derecede, yedi grup orta derecede ve altı grup yüksek derecede sonuçları tablolaştırabilip, gerekli işlemleri yapabildikleri görülmüştür.

Birinci grup test sonuçlarını tablolaştırıp, işlem yapabilmede üç etkinlik de yüksek derecededir. İkinci grup birinci etkinlikte orta, ikinci etkinlikte az ve üçüncü etkinlikte yüksek derecede sonuçları tablolaştırıp, işlem yapabilmektedir. Üçüncü grup birinci etkinlikte az, iki ve üçüncü etkinlikte orta derecede tablolaştırma ve işlem yapabilmektedir. Dördüncü grup tablolaştırma ve işlem yapmada bir ve üçüncü etkinlikte orta, ikinci etkinlikte az derecededir. Beşinci grup ve Altnncı grup birinci etkinlikte orta, ikinci etkinlikte az ve üçüncü etkinlikte yüksek derecede tablolaştırma ve işlem yapabilmektedir. 3.2.13. Madde 13. "Öğrenciler elde edilen verilere göre grafik çizebilirler." Performansına İlişkin Bulgular

On üçüncü madde ile ilgili frekans değerleri Grafik 25 ve 26 'da verilmiştir.
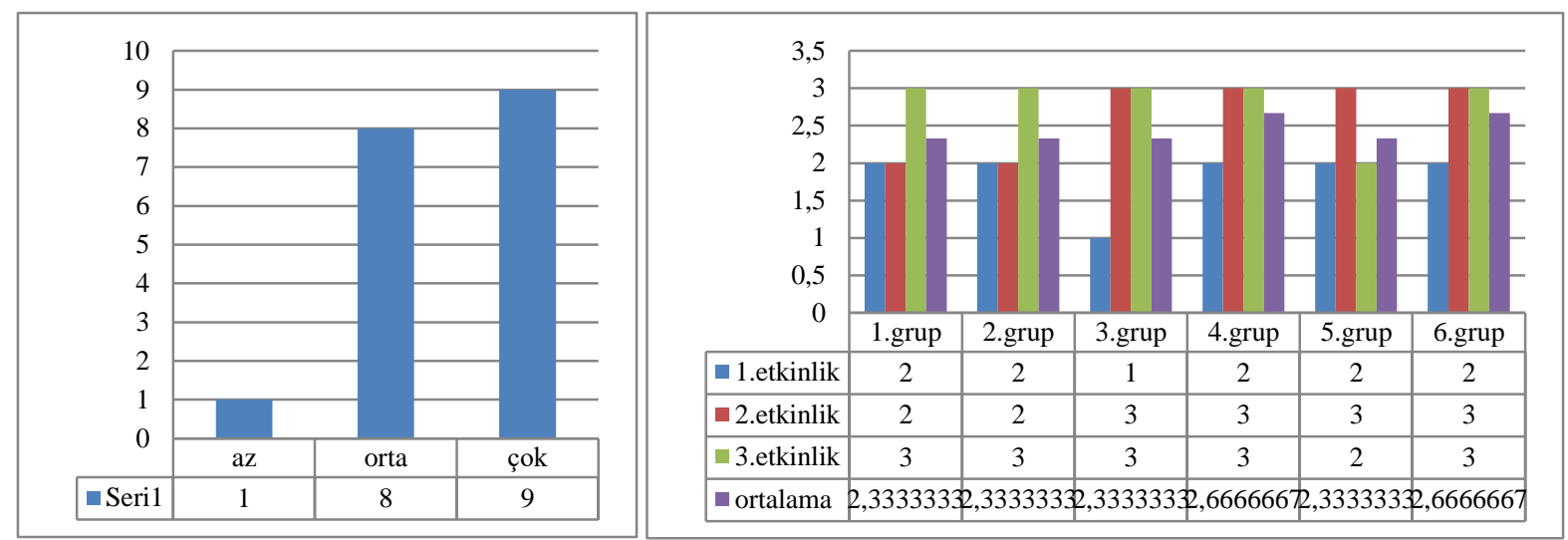

Grafik 25. 13. Performansın Frekansları Grafik 26. 13. Performansı Başarabilme Derecesi

Altı gruba yapılan üç farklı etkinlik için (toplam $18 \mathrm{kez}$ ) on üçüncü performans frekansına bakıldığında sınıftaki bir grup az derecede, sekiz grup orta derecede ve dokuz grup yüksek derecede grafik çizebildikleri görülmüştür.

Birinci ve ikinci grup, grafik çizebilmede bir ve ikinci etkinlikte orta, üçüncü etkinlikte yüksek derecededir. Üçüncü grup, birinci etkinlikte grafik çizebilmede az derecede, iki ve üçüncü etkinlikte yüksek derecededir. Dördüncü grup, birinci etkinlikte orta, iki ve üçüncü etkinlikte yüksek derecede grafik çizebilmektedir. Beşinci grup, bir ve üçüncü etkinlikte orta, ikinci etkinlikte yüksek derecede grafik çizebilmektedir. Altıncı grup, grafik çizebilmede birinci etkinlikte orta, iki ve üçüncü etkinlikte yüksek derecededir. 3.2.14. Madde 14. "Öğrenciler elde edilen verilere göre en iyi tasarımı seçebilirler."
Performansına İlişkin Bulgular

On dördüncü madde ile ilgili frekans değerleri Grafik 27 ve 28 'de verilmiştir.

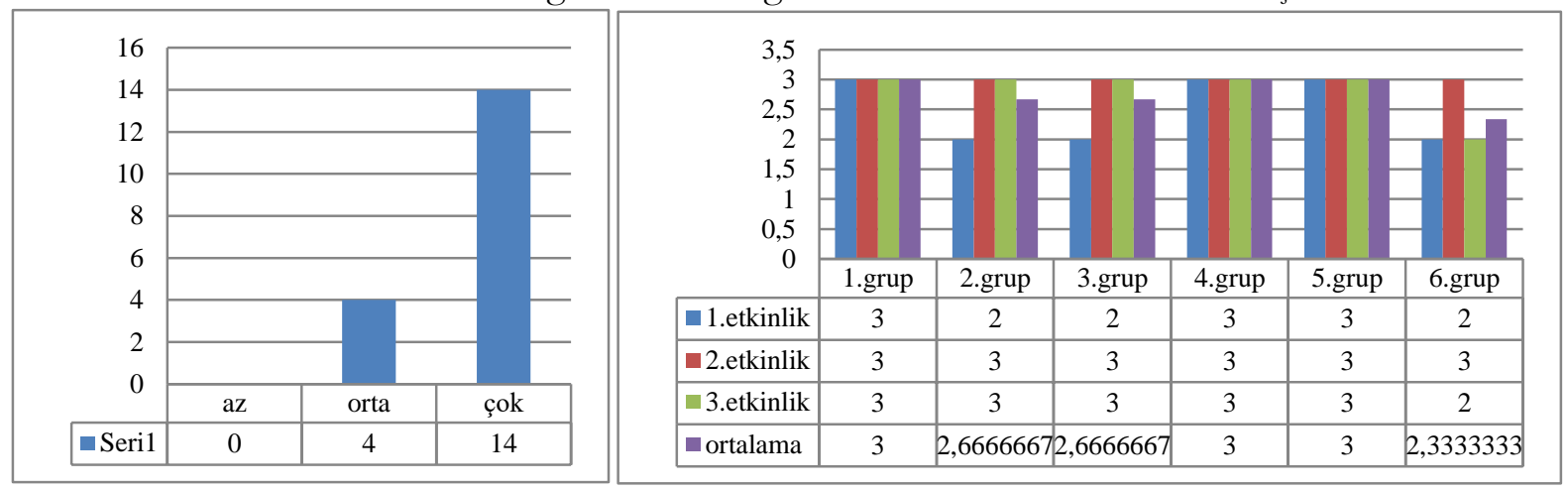

Grafik 27. 14. Performansın Frekansları Grafik 28. 14. Performansı Başarabilme Derecesi 
Köngül, Ö., \& Yildırım, M. (2021). Title in article's language. Journal of Human Sciences, 18(2), 159-184. doi: $10.14687 /$ jhs.v18i2.6066

Alı gruba yapılan üç farklı etkinlik için (toplam 18 kez) on dördüncü performans frekansına bakıldığında sınıftaki sıfır grup az derecede, dört grup orta derecede ve on dört grup yüksek derecede en iyi tasarımı seçebildikleri görülmüştür.

Birinci grup elde edilen verilere göre en iyi tasarımı seçmede üç etkinlikte de yüksek derecededir. İkinci grup ve üçüncü grup birinci etkinlikte orta, ikinci ve üçüncü etkinliklerde yüksek derecede en iyi tasarımı seçebilmektedir. Dördüncü ve beşinci grup 3 etkinlikte de en iyi tasarımı seçmede yüksek derecededir. Altıncı grup bir ve üçüncü etkinlikte orta derecede, ikinci etkinlikte yüksek derecede en iyi tasarımı seçebilmektedir.

\subsubsection{Madde 15. "Öğrenciler kendi tasarımlarının güçlü ve eksik yönlerini belirler."} Performansına İlişkin Bulgular

On beşinci madde ile ilgili frekans değerleri Grafik 29 ve 30'da verilmiştir.
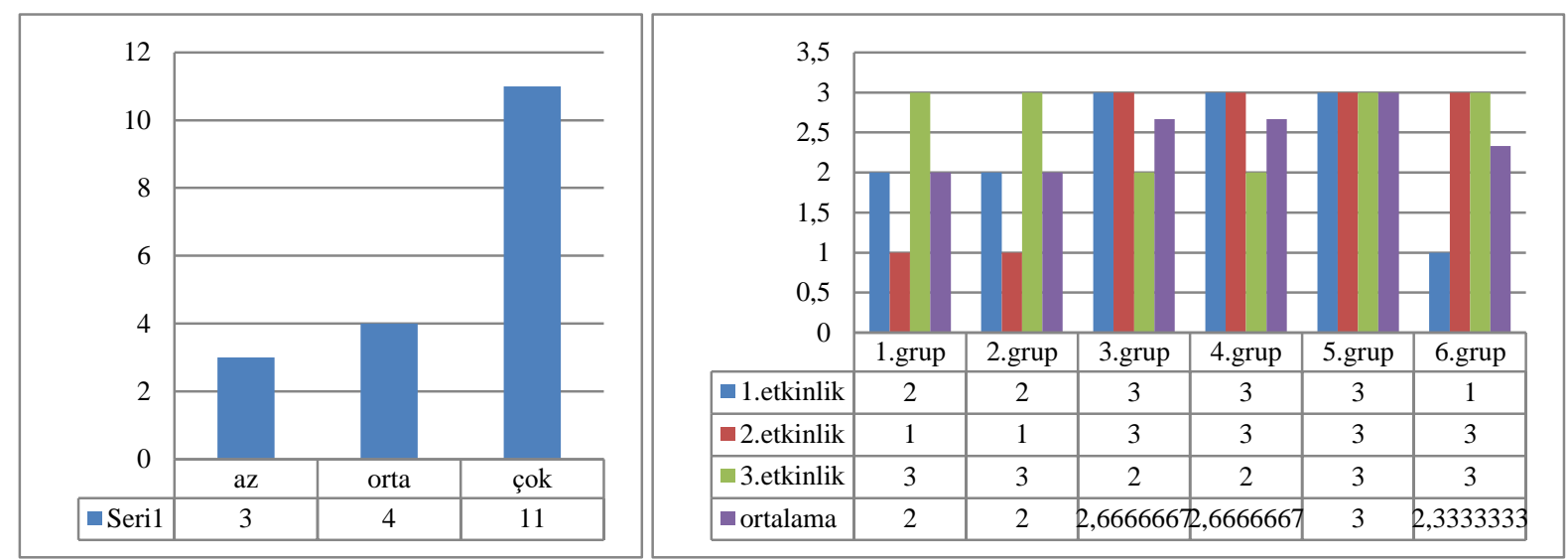

Grafik 29. 15. Performansın Frekansları Grafik 30. 15. Performansı Başarabilme Derecesi

Altı gruba yapılan üç farklı etkinlik için (toplam $18 \mathrm{kez}$ ) on beşinci performans frekansına bakıldığında sınıftaki üç grubun az derecede, dört grubun orta derecede ve on bir grubun yüksek derecede tasarımın güçlü ve eksik yönlerini belirleyebildiği görülmüştür.

Birinci ve ikinci grup, tasarımın eksik ve güçlü yönlerini belirlemede birinci etkinlikte orta, ikinci etkinlikte az, üçüncü etkinlikte yüksek derecededir. Üçüncü ve dördüncü grup, tasarımın eksik ve güçlü yönlerini belirlemede bir ve ikinci etkinlikte yüksek, üçüncü etkinlikte orta düzeydedir. Beşinci grup, üç etkinlikte de yüksek derecede tasarımın güçlü ve eksik yönlerini belirleyebilmektedir. Altıncı grup, birinci etkinlikte az, iki ve üçüncü etkinlikte yüksek düzeyde tasarımın güçlü ve eksik yönlerini belirleyebilmektedir.

\subsubsection{Grupların Performanslarının Puan Karşılaştırması}

Grafik 31'de her grubun 15 performans için aldıkları puanlar verilmiştir. Grupların üç etkinlik için aldıkları toplam performans puanları incelendiğinde; en yüksek puanı beşinci grubun ve en düşük puanı da üçüncü grubun aldığı görülmektedir. Tüm grupların toplam en yüksek puanı topladıkları performans 14. performans ve en düşük puanı topladıkları performans birinci performans olmuştur.

Grafik 31. Grupların Performans Puanları

Grafik 31. Grupların Performans Puanları

Grafik 31. Grupların Performans Puanları

Grafik 31. Gruplann Performans Puanlar1

Grafik 31. Gruplanın Performans Puanları 
Köngül, Ö., \& Yıldırım, M. (2021). Title in article's language. Journal of Human Sciences, 18(2), 159-184. doi: $10.14687 /$ jhs.v18i2.6066

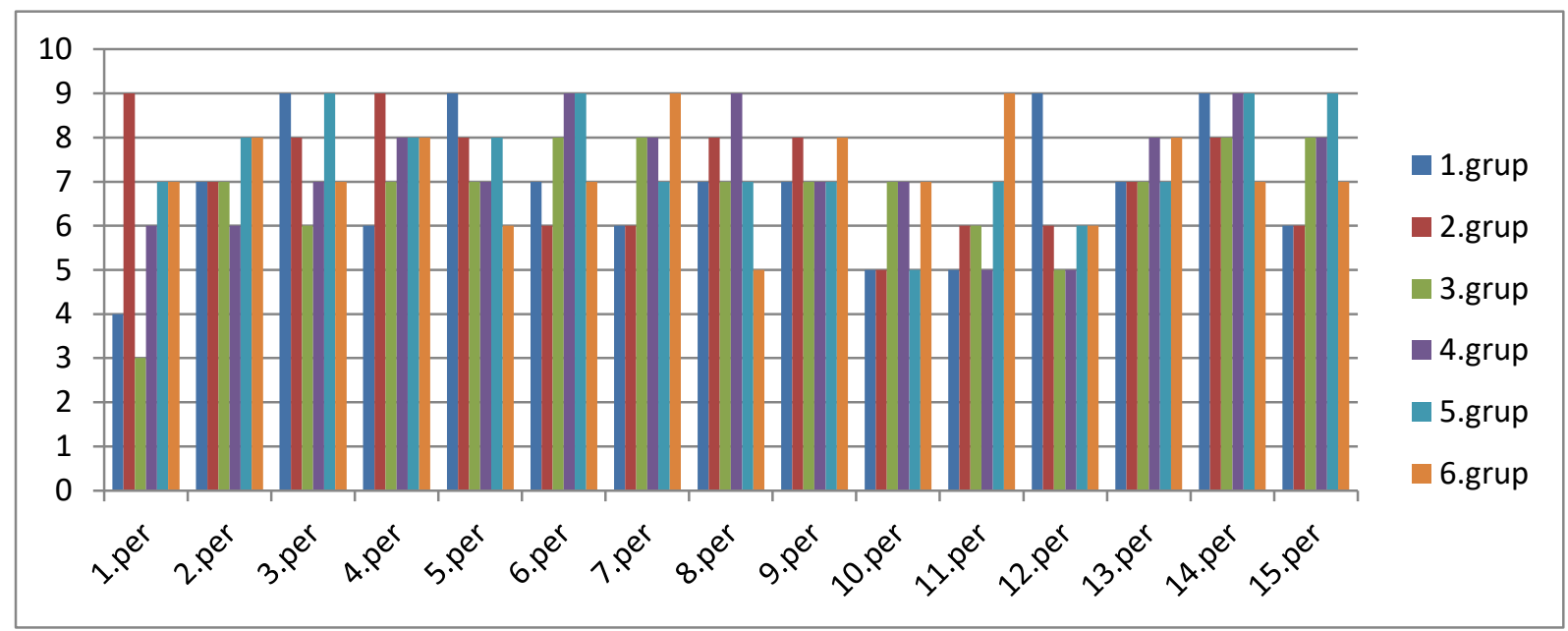

Grafik 31. Grupların Performans Puanları

\section{Tartışma ve Sonuç}

STEM uygulamaları ile desteklenmiş fen öğretiminin ortaokul altıncı sınıf öğrencilerinin bilimsel süreç becerilerine ve STEM performanslarına olan etkisini inceleyen bu çalışmanın sonucunda, çalışma grubunun bilimsel süreç becerileri ön test-son test puanları arasında anlamlı bir farklılık olduğu görülmektedir. Buna göre, STEM uygulamaları ile desteklenmiş fen öğretimi öğrencilerin bilimsel süreç becerilerinin gelişimini olumlu yönde etkilediği söylenebilir. Bu yargiyı, etkinlik kağıdı analizlerinde kullanılan rubrik sonuçları da (1., 2., 8. ve 10. maddeler ile) desteklemektedir.

STEM uygulamaları sürecinde uygulanan etkinlik kâğıtlarının analizinde de öğrencilerin problem cümlesi belirleme ve belirlenen problem cümlesine çözüm bulabilmede diğer maddelere göre düşük performans gösterseler de genel olarak diğer performanslar açısından (tasarımı planlama, gerçekleştirme, test etme, değişkenleri belirleme gibi) ortanın üzerinde bir performans gösterebilmişlerdir. Ayrıca öğrencilerin tasarladıkları ürünü test edip değişkenlerini bulabilmede yüksek puanlar elde ettikleri görülmüştür. BSB testi ve öğrenci etkinlik kâğıtlarından elde edilen verilere dayalı olarak STEM uygulamaları ile desteklenmiş fen öğretiminin öğrencilerin bilimsel süreç becerilerinin gelişimine pozitif yönde katkısı olduğu söylenebilir.

Bu çalışmanın sonuçları, alanyazındaki STEM uygulamaları kullanılarak yapılan öğretimlerle ortaokul öğrencilerinin bilimsel süreç becerilerini geliştirdiğini gösteren şu çalışmaların sonuçları ile örtüşmektedir: Yamak, Bulut ve Dündar (2014) yaptıkları çalışmada STEM etkinliklerinin ortaokul beşinci sınıf öğrencilerinin bilimsel süreç becerilerine olan etkisi incelenmiş ve öğrencilerin bilimsel süreç becerilerini arttırdığı sonucuna ulaşmışlardır. Lestari, Sarwi ve Sumarti (2018) çalışmalarında STEM'e dayanan etkinlik ve projelerinin beşinci sınıf öğrencilerinin bilimsel süreç becerilerine olumlu etkisi olduğu sonucunu ortaya koymuşlardır. İzgi'de (2020) çalışmasında STEM yaklaşımının yedinci sınıf öğrencilerinin bilimsel süreç becerilerine olan etkisini araştırmış ve bu çalışmanın sonuçlarını destekler şekilde olumlu yönde katkısı olduğunu bulmuştur.

Araştırmada öğrencilerin her bir etkinlik için süreçle ilgili performansları da ortaya çıkarılmıştır. Çalışmaya katılan altı grubun her bir etkinlik ile ilgili performanslanı incelendiğinde en çok puanı toplayıp en başarılı olan grup beşinci grup olmuştur. Süreç içerisinde işbirlikli çalışmayı en etkili yürütmüş ve aldığ1 dönütlerden en iyi performansı gerçekleştirmişlerdir. Grupların en yüksek puanı topladığı performans olan "Öğrenciler elde edilen verilere göre en iyi tasarımı seçebilirler. " olmuştur. Her grup verilen kriterleri göz önünde bulundurarak en iyi tasarımı seçme konusunda başarı göstermişlerdir. Gruplar en düşük puanı birinci performans olan "Öğrenciler problem cümlesini belirler" olmuştur. Verilen senaryodan hareketle problem cümlesini bulmak en başarısız oldukları performans olmuştur. İkinci grup bu performans görevinde tam puan almış ve en başarılı grup 
olmuştur. Tüm performanslar incelendiğinde birçok performansta grupların STEM etkinlikleri sonucunda puanlarını arttırdığı ve genel olarak ortanın üzerinde bir performans gösterdiği sonucuna ulaşılmıştır.

Öğrencilerin çoğunluğu STEM etkinlikleri süreci sonunda problem cümlesini belirleyebilmiştir. Her grup aynı düzeyde problem cümlesi belirleyemese de öğrencilerin çoğunluğu problem cümlesini iyi ve orta düzeyde belirleyebilmektedir. Alanyazında da bu sonuca ulaşan çalışmaları görmek mümkündür. Şen (2018) tarafindan yapılan çalışmada STEM uygulamalarında üstün zekâlı öğrencilerin kullandığı becerileri incelemiştir. Çalışmasında gerçek yaşamda yer alan karmaşık problem durumları verilmiş ve öğrenciler başarılı bir şekilde problemi belirleyip mühendislik becerilerini kullanıp tasarımı gerçekleştirebilmiştir. Pekbay'ın (2017) ortaokul öğrencileri ile yapı̆̆1 çalışmada, öğrencilerin günlük yaşamda problem çözme becerilerini geliştirdiğini belirlemiştir. Öğrencilerin süreç içerisinde problem durumlarını daha rahat analiz edebildikleri görülmüştür.

Öğrencilerin etkinlik kâğıtları incelendiğinde öğrencilerin yüksek düzeyde probleme yönelik çözüm önerisi belirleyebildikleri görülmüştür. Öztürk (2018) tarafindan yapılan çalışmada STEM eğitimi ile problem çözme becerilerinin pozitif bir ilişkisi olduğu belirtilmiştir. Çalışmada STEM eğitiminin çoklu bakış açısı ve çoklu çözüm üretme becerisi kazandırdığı ifade edilmektedir. Koç (2019) tarafindan sekizinci sınıf öğrencileriyle yapılan çalışmada ise öğrencilerin bir kısmının karşlaştıkları probleme çözüm yolu bulduğu görülmüştür. Yapılan bu çalışmalardan elde edilen sonuç, bu çalışmayı desteklemektedir.

Öğrenciler, yüksek düzeyde problemin çözümüne yönelik tasarım yapabilmektedirler. Altaş (2018)'ın yaptı̆̆1 çalışmada STEM eğitimi alan öğretmen adaylarının mühendislik tasarım becerileri incelenmiştir. Öğretmen adaylarının tasarım yapımını diğer aşamalara göre daha iyi yaptıklarını belirtmiştir. Bu çalışmada incelenen ortaokul öğrencilerinin de sonucu aynı yönde olmuştur. Kayabaş (2019) ortaokul öğrencileriyle yaptığı çalışmada, bu çalışmanın sonuçlarına benzer şekilde öğrencilerin tasarım çizme becerilerinin geliştiğini göstermiştir.

Öğrencilerin tasarım planı yaparken yüksek düzeyde kriterleri göz önüne aldıkları belirlenmiştir. Altaş (2018) da çalışmasında bu çalışmada olduğu gibi öğretmen adaylarının tasarım planlarında kriterlere dikkat ettiklerini söylemiştir.

Çalışmada, öğrencilerin problemin çözümüne yönelik olası tasarım planlarını detaylı bir şekilde iyi düzeyde çizebildikleri görülmüştür. Ercan'da (2014) çalışmasında öğrencilerin mühendislik tasarım sürecinde ilk tasarım planlarının kriterleri pek karşılayamadığı ancak sonra çizdikleri tasarım planlarının kriterlere daha uygun olduğunu belirtmiştir.

Öğrenciler STEM eğitimi kapsamında tasarım planları yaparken, tasarım planları üzerinde tartışı bir tasarım planı seçip çizmede iyi düzeydedirler. Ercan (2014)'ün yaptığı çalışmada öğrencilerin tasarım temelli fen uygulamaları süresince en uygun çözüm önerisinin belirlenebilmesi için gerekli yeterlilikler açısından gelişme gösterdiklerini belirtmiştir. Bu çalışmada da STEM destekli fen öğretimi süresince öğrencilerin belirlenen kriterlere en uygun tasarım planını seçmede yeterli düzeye ulaşmak için gelişme gösterdikleri belirlenmiştir.

Öğrencilerin tasarımda kullanacakları malzemeleri kriterleri düşünerek seçmede iyi düzeyde oldukları belirlenmiştir. Öner ve Yılmaz (2019)' in ortaokul öğrencileriyle yaptı̆̆ı çalışmada STEM eğitiminin öğrencilerin bilimsel sorgulama becerilerini geliştirdiği görülmüştür. Altaş (2018), yaptığ1 çalışmada STEM etkinliklerinde öğretmen adaylarının tasarım yaparken malzeme aşamasında sınırlılıkları ve başarı kriterini göz önünde bulundurduklarını, birçok malzeme içinden kriterlere en uygun olanı daha kısa sürede seçmeleri açısından karar verebilme becerilerinin geliştiğini ifade etmiştir. $\mathrm{Bu}$ çalışmada da öğrenciler, tasarım görevlerini gerçekleştirirken belirlenen kriterlere en uygun malzemeleri seçme konusunda STEM etkinlikleri süresince gelişme göstermiştir.

Öğrenci etkinlik kâğıtları incelendiğinde, öğrenciler tasarımlarını test edip neleri test ettiklerini belirlemede iyi düzeyde oldukları görülmüștür. Yaptıkları tasarımın deneme süresince neleri test edebileceğini iyi derecede tahmin etmiş ve test ettikleri değişkenleri belirleme konusunda zorluk yaşamamışlardır. Ercan (2014) tarafindan yapılan çalışmada öğrencilerin tasarım sürecinde tasarımlarını yapıp, test etme aşamasında gerekli olan yeterliliklerinin geliştiğini ifade etmiştir. Bu 
Köngül, Ö., \& Yildırım, M. (2021). Title in article's language. Journal of Human Sciences, 18(2), 159-184. doi:10.14687/jhs.v18i2.6066

çalışmada da STEM etkinlik sürecinde öğrenciler, tasarımlarını yapmada ve test etme aşamasında gerekli olan becerileri kazanmış ve gelişme göstermişlerdir.

Öğrenciler STEM etkinlikleri sürecinde tasarımları ve tasarımlarını test etmek için gerekli olan teknolojik aletleri iyi düzeyde kullanabildikleri görülmüştür. Kavak (2019) yaptı̆̆ çalşmada öğrencilerin STEM etkinlerinde teknolojiye olan tutumlarının arttı̆̆ını belirtmiştir. Bu çalışmada da STEM etkinliklerinin tasarım sürecinde, tasarımı test etme sürecinde gerekli olan teknolojik aletleri süreç içerisinde daha iyi kullanabildikleri görülmüştür. Bu doğrultuda STEM etkinlikleri öğrencileri, teknolojik aletleri kullanmasında geliştirmiştir.

Öğrencilerin STEM etkinleri sürecinde tasarladıkları deneyin bağımlı, bağımsız ve kontrollü değişkenlerini belirlemede iyi düzeyde oldukları görülmüştür. Bu doğrultuda öğrencilerin STEM etkinlikleri sürecinde bilimsel süreç becerilerinin geliştiği sonucuna ulaşılır. Alan yazında da benzer sonuca ulaşan çalışmalar mevcuttur. Taştan Akdağ (2017), ortaokul öğrencileriyle yaptı̆̆1 çalışmada STEM uygulamalarının bilimsel süreç becerilerini geliştirdiğini belirtmiştir. Yine Gökbayrak (2017) yaptığı çalışmada benzer bir sonuca ulaşmıştır. Elde edilen sonuçlar, bu çalışmanın sonuçlarını destekler niteliktedir.

STEM etkinliklerinde öğrenciler tasarımı deneme sonucunda ne olmasını beklediklerini belirtmede iyi düzeydedirler. Tasarım görevlerini belirlenen kriterlere göre yapan öğrenciler, tasarımlarının test sonucunda ne olmasını beklediklerini çoğunlukla doğru bir şekilde tahmin etmişlerdir. Altaş (2018), STEM eğitiminin üretken düşünmeyi geliştirdiğini belirtmiştir. Pekbay (2017), STEM eğitiminin yaratıcı düşünme becerilerini geliştirdiğini belirtmiştir. Bu çalışmada elde edilen sonuç da bu ifadeyi desteklemektedir.

Öğrenciler STEM etkinlikleri sürecinde test ettikleri tasarımlarından elde ettikleri verileri tablolaştırıp, gerekli işlemleri yapma ve grafik çizebilme açısından iyi düzeydedirler. Özçelik ve Akgündüz (2018) tarafindan yapılan çalışmada üstün yetenekli öğrencilerin STEM etkinlikleri sonucunda matematiksek işlemleri ürün oluşturma aşamasına entegre etme becerilerinin arttırdığını belirtmiştir. Bu çalışma da aynı sonuca ulaşmıştır. Farklı sonuca ulaşan çalışmalar da mevcuttur. Aydın ve Karslı Baydere (2019) tarafindan ortaokul öğrencileriyle yapılan çalışmada öğrenciler süreç içerisinde matematiksel işlem yapmakta zorlandıklarını ifade etmişlerdir. Bu durumu öğrencilerin matematik alanında eksikliklerinin olmasına bağlamışlardır.

Öğrenciler tasarım görevlerini gerçekleştirirken elde ettikleri bulgulara göre en iyi tasarımı iyi düzeyde seçebilmişleridir. Bozkurt (2014) öğretmen adayları ile yaptı̆̆ı çalışmasında, tasarım sürecinde öğretmen adaylarının birçok kriteri ve alternatif çözümü olan gerçek yaşam problemlerinden kriterlerin göreli önemine dikkat ederek en iyi çözümü seçtikleri ve bunun da tasarım temelli eğitimin karar verme becerilerini geliştirdiğini söylemiştir. Ercan (2014) tarafindan yapılan çalışmada tasarım temelli fen eğitiminin karar verme becerisini arttırdığı belirlenmiştir. Bu çalışmadan elde edilen sonuç da bunu destekler nitelikte olmuştur.

Öğrenciler STEM etkinliklerinde tasarladıkları tasarımın güçlü ve eksik yönlerini iyi düzeyde belirleyebilmişlerdir. Altaş (2018), çalışmasında öğretmen adaylarının STEM eğitiminin üretken düşünme, belirli bir konuda tartışma yapabilme ve eleştirel bakış açılarının geliştiğini belirtmiştir. $\mathrm{Bu}$ çalışmada, öğrencilerin tasarımlarının güçlü ve eksik yönlerini ifade edebilmeleri tasarımlarına eleştirel bir yönde bakabildiklerini ve üretken düşünceye sahip olduklarını göstermektedir. Kayabaş (2019)'ın sekizinci sınıf öğrencileriyle yaptı̆̆ çalışmada probleme dayalı okul dışı STEM etkinliklerinin öğrencilerin karar verme becerilerini geliştirdiği görülmüştür.

STEM etkinlikleri ile desteklenmiş fen öğretimi sürecinde öğrencilere verilen etkinlik kâğıtları, öğrencilere süreç içerisinde rehberlik etmiş ve öğrencilerin bu süreçteki gelişimleri belirlenmiştir. STEM etkinlikleri ile desteklenmiş fen öğretiminin öğrencilerin bilimsel süreç becerilerini ve STEM'e yönelik becerilerini geliştirdiği söylenebilir.

Çalısmanın sonucunda öğrencilerin STEM etkinlikleri ile bilimsel süreç becerilerini ve mühendislik becerilerini başarıyla kullandığı görülmüştür. Bu çalışmanın ardından öğrencilerin STEM uygulamaları sırasındaki performanslarının bilimsel süreç becerileri ile yaklaşımının 21. yüzyıl 
Köngül, Ö., \& Yildırım, M. (2021). Title in article's language. Journal of Human Sciences, 18(2), 159-184. doi: $10.14687 /$ jhs.v18i2.6066

becerilerinden olan eleştirel düşünme, yaratıclık, işbirlikli çalışma ve girişimcilik gibi farklı becerilere nasıl bir etkisinin olduğunun ortaya konulması alanyazına katkı sağlayacağı için çalışılması önerilir.

\section{Kaynakça}

Aydın, E., \& Karslı Baydere, F. (2019). Yedinci sınıf öğrencilerinin STEM etkinlikleri hakkındaki görüşleri: karışımların ayrıştırılması örneği. OMÜ Eğitim Fakültesi Dergisi, 38(1), 35-52.

Altaş, S. (2018). STEM eğitimi yaklaşımmm smif ögretmeni adaylarmm mühendislik tasarm süreçlerine, mühendislik ve teknoloji algzlarna etkisinin incelenmesi [Yayımlanmamış yüksek lisans tezi]. Muş Alparslan Üniversitesi Fen Bilimleri Enstitüsü.

Benek, İ. (2019). Sosyobilimsel STEM etkinliklerinin ögrencilerin tutumlarna ve 21.yy becerilerine etkisinin incelenmesi [Yayımlanmamış Doktora Tezi]. İstanbul üniversitesi-Cerrahpaşa, Lisansüstü Eğitim Enstitüsü.

Bozkurt, E. (2014). Mühendislik tasarm temelli fen eğitiminin fen bilgisi ögretmen adaylarmmn karar verme becerisi, bilimsel süreş becerileri ve sürece yönelik algularnna etkisi [Yayımlanmamış doktora tezi]. Gazi Üniversitesi Eğitim Bilimleri Enstitüsü.

Burns, J. C., Okey, J. R., \& Wise, K. C. (1985). Development of an Integrated Process Skill Test: TIPS II. Journal of Research in Science Teaching. 22, 169177. https://doi.org/10.1002/tea.3660220208

Büyüköztürk, Ş., Kılıç Çakmak, E., Akgün, Ö. E., Karadeniz, Ş., \& Demirel, F. (2019). Eğitimde bilimsel arasturma yöntemleri. Pegem. https://doi.org/10.14527/9789944919289

Büyüköztürk, Ş. (2007). Deneysel desenler: Öntest-sontest kontrol grubu desen ve veri analiæi. Pegem. https://doi.org/10.14527/9789756802434

Can, A. (2018). SPSS ile nicel veri analizi. Pegem. https://doi.org/10.14527/9786053644484

Chachashvili-Bolotin, S., Milner-Bolotin, M. ve Lissitsa, S. (2016). Examination of factors predicting secondary students' interest in tertiary STEM education. International Journal of Science Education, 38(3), 366- 390

Creswell, J. W. (2014). Araştırma deseni: Nitel, nicel ve karma yöntem yaklaşımlarn (4.baskıdan çeviri). (S.B. Demir Çev. Ed). Eğiten Kitap.

Creswell, J. W. \& Plano Clark, V. L. (2014). Karma yöntem arastırmalar tasarmı ve yürütülmesi. (Y. Dede ve S.B. Demir, Çev. Ed.).Anı.

Çakar, E. (2008). 5.smnf fen ve teknoloji programmmn bilimsel süreç becerileri kazammlarmm gerçekleșme düzeylerinin belirlenmesi [Yayımlanmamış yüksek lisans tezi]. Süleyman Demirel Üniversitesi Sosyal Bilimler Enstitüsü.

Çetin, M., \& Demircan H.Ö. (2020). STEM Education in Early Childhood. Inonu University Journal of the Faculty of Education, 21(1), 102-117. DOI: 10.17679/inuefd.437445

Daymaz, B. (2019). Bilim, teknoloji, mühendislik ve matematik (STEM) etkinliklerinin 7.smnf ögrencilerinin matematik bassar, motivasyon ve STEM kariyer alanlarna etkisi [Yayımlanmamış Yüksek Lisans Tezi]. Kocaeli Üniversitesi, Fen Bilimleri Enstitüsü.

Değirmenci, S. (2020). STEM eğitimi almışögretmenlerin STEM öz yeterliliklerinin ve uygulamalarnda teknoloji ve mühendislike entegrasyonu açısından yaşadıklar sorunlarn belirlenmesi [Yayımlanmamış yüksek lisans tezi]. Marmara Üniversitesi Eğitim Bilimleri Enstitüsü.

Ercan, S. (2014). Fen eğitiminde mühendislik uygulamalarnn kullanım: Tasrm temelli fen eğitimi [Yayımlanmamış doktora tezi]. Marmara Üniversitesi Eğitim Bilimleri Enstitüsü.

Gökbayrak, S., \& Karışan, D. (2017). STEM etkinliklerinin fen bilgisi öğretmen adaylarının bilimsel süreç becerilerine etkisi. Batı Anadolu Eğitim Bilimleri Dergisi, 63-84.

Hançer, A. H., Şensoy, Ö., \& Yıldırım, H. İ. (2003). İlköğretimde çağdaş fen bilgisi öğretiminin önemi ve nasıl olması gerektiği üzerine bir değerlendirme. Pamukkale Üniversitesi Eğitim Fakiltesi Dergisi, 80-88. 
Köngül, Ö., \& Yıldırım, M. (2021). Title in article's language. Journal of Human Sciences, 18(2), 159-184. doi:10.14687/jhs.v18i2.6066

İzgi, S. (2020). Fen bilimleri dersi elektrik enerjisinin dönüsümü konusuna 5E modeli ile temellendirilmiş bilim, teknoloji, mühendislik ve matematik (STEM) yaklasımmnn 7. sme ögrencilerinin akademik basar ve bilimsel süreç becerilerine etkisi [Yayınlanmamış Yüksek Lisans Tezi] Mustafa Kemal Üniversitesi, Fen Bilimleri Enstitüsü.

Kale, S. (2019). STEM uygulamalarının okul öncesi öğretmenlerinin bilimsel süreç becerilerine etkisinin incelenmesi [Yayımlanmamış Yüksek Lisans Tezi]. Manisa Celal Bayar Üniversitesi Fen Bilimleri Enstitüsü.

Kara, E. (2017). Tabmin et-gö̊le-açıkla stratejisine dayal fen ögretiminin ögrencilerin bilimsel süreç becerilerine ve başarısına etkisinin incelenmesi [Yayımlanmamış yüksek lisans tezi]. Marmara Üniversitesi Eğitim Bilimleri Enstitüsü.

Karadeniz, H. (2019). STEM uygulamalarmm ögrencilerin STEM farkindahklar üzerine ve 'Üggenler' ünitesindeki başarlarnmn kahıllhk düzeyine etkisi [Yayımlanmamış Yüksek Lisans Tezi]. Bayburt üniversitesi, Lisansüstü Eğitim Enstitüsü.

Kavak, T. (2019). STEM uygulamalarnin 4. sme ögrencilerinin fen ve teknolojize yönelik tutumlarna, bilimsel süreç ve problem çözme becerilerine etkisi [Yayımlanmamış yüksek lisans tezi]. Fırat Üniversitesi Eğitim Bilimleri Enstitüsü.

Kayabaş, B.T. (2019). Probleme dayah okul dısıı stem etkinliklerinin öğrencilerin akademik bașarlarna ve karar verme becerilerine etkisi [ Yayımlanmamış Yüksek Lisans Tezi]. Muğla Sıtkı Koçman Üniversitesi Eğitim Bilimleri Enstitüsü.

Koç, N. (2019). Tasarm temelli fen eğitiminde biltemm uygulamalarnm bilimsel süreş becerilerine, FETEMM meslek ilgilerine ve stem tutumlarna etkisi [Yayımlanmamıs Yüksek Lisans Tezi]. Fırat Üniversitesi Eğitim Bilimleri Enstitüsü.

Lestari, T., Sarwi, S., \& Sumarti, S. (2018). STEM-Based Project Based Learning Model to Increase Science Process and Creative Thinking Skills of 5th Grade. Journal of Primary Education, 7(1), 1824. https://doi.org/10.15294/ipe.v7i1.21382

Öner, G., \& Yılmaz, Y., Ö. (2019). Ortaokul öğrencilerinin problem çözme ve sorgulayıcı öğrenme becerileri algıları ile stem'e yönelik alg1 ve tutumları arasındaki ilişkinin incelenmesi. Cumburiyet Uluslararası Eğitim Dergisi, 837-861

Özçelik, A. \& Akgündüz, D. (2018). Üstün/Özel Yetenekli Öğrencilerle Yapılan Okul Dışı STEM Eğitiminin Değerlendirilmesi. Trakya Üniversitesi Eğitim Fakültesi Dergisi, 334-351.

Öztürk, S. C. (2018). STEM eğitiminin fen bilgisi ögretmen adaylarmm problem çözme ve eleştirel düsü̈nme becerileri üzerine etkisi [Yayımlanmamış yüksek lisans tezi]. Erzincan Binali Yıldırım Üniversitesi Fen Bilimleri Enstitüsü.

Pekbay, C. (2017). Fen teknoloji mühendislik ve matematik etkinliklerinin ortaokul ögrencileri üzerindeki etkileri [Doktora tezi]. HacettepeÜniversitesi Eğitim Bilimleri Enstitüsü.

Sarıçam, U., \& Yıldırım, M. (2021). The effects of digital game-based STEM activities on students' interests in STEM fields and scientific creativity: Minecraft case. International Journal of Technology in Education and Science (IJTES), 5(2), 166-192. https://doi.org/10.46328/ijtes.136.

Smith IV, D.H., Hao, Q., Dennen, V., Tsikerdekis, M., Barnes, B., Martin, 1. \& Tresham, N. (2020). Towards understanding online question \& answer interactions and their effects on student performance in large-scale STEM classes. Int J Educ Technol High Educ 17( 20), 1-15. https://doi.org/10.1186/s41239-020-00200-7.

Sürmeli, H , Yıldırım, M , Göcük, A, Sevgi, Y . (2018). Secondary school students' performance and opinions towards activities based on engineering design process. Cukurova University Faculty of Education Journal, 47 (2), 844-872. https://doi.org/10.14812/cuefd.395594.

Şen, C. (2018). Mühendislik tasarm odakh bütünlessik STEM etkinliklerinde üstün zekalı ve yetenekli ögrencilerin kullandiğ becerileri [Yayımlanmamıs Doktora Tezi]. Hacettepe Üniversitesi Eŭitim Bilimleri Enstitüsü.

Şirin, E. (2020). Girişimcilik odakl STEM etkinliklerinin 7.smufögrencilerinin girişimcilik becerilerine ve STEM tutumlarna etkisi [Yayımlanmamıs Yüksek Lisans Tezi]. Van Yüzüncü Yll Üniversitesi, Eğitim Bilimleri Enstitüsü. 
Köngül, Ö., \& Yildırım, M. (2021). Title in article's language. Journal of Human Sciences, 18(2), 159-184. doi: $10.14687 /$ jhs.v18i2.6066

Taştan Akdağ, F. (2017). STEM uygulamalarmm öğrencilerin akademik bașar, bilimsel süreç ve yaşam becerileri üzerine etkisi [Yayımlanmamış doktora tezi]. Ondokuz Mayıs Üniversitesi Eğitim Bilimleri Enstitüsü.

Ünal, M. (2019). 4-6 yaş okul öncesi çocuklarna etkinlik, temelli STEM eğitiminin bilimsel süreş becerilerine etkisi [Yayımlanmamış Yüksek Lisans Tezi]. Bolu Abant Baysal Üniversitesi Eğitim Bilimleri Enstitüsü.

Yamak, H., Bulut, N., \& Dündar, S. (2014). 5. Sınıf Öğrencilerinin Bilimsel Süreç Becerileri ile Fene Karşı Tutumlarına FeTeMM Etkinliklerinin Etkisi. Gefad, 249-265.

Yılmaz, A., E. (2019). FeTeMM uygulamalarının ortaokul 7.sınıf öğrencilerinin fen bilimleri dersi tutumlarına ve bilimsel süreç becerilerine etkisinin incelenmesi [Yayımlanmamış Yüksek Lisans Tezi]. Bolu Abant Baysal Üniversitesi Eğitim Bilimleri Enstitüsü.

\section{Extended English Summary}

\section{Introduction}

The age we live in is the age of science and technology. With the rapidly developing science and technology, it is inevitable that human life will change. It is also extremely important for people to adapt to changing conditions. In order to pass this adaptation process, people must be innovative, investigative and questioning, as well as gain decision-making and problem-solving skills (Yamak, Bulut, \& Dündar, 2014).

Raising qualified people is one of the most important functions of educational activities. By qualified person; we mean a person who understands, knows and uses the benefits of the age. One of the most important benefits of our age is technology. Based on this, qualified people can be defined as innovative and productive people who can keep up with the developing technology. The world we live in requires people to be productive. In order for this to happen, human beings must gain an innovative, investigative and questioning role. The most important task in achieving this role falls on educational activities (MoNE 2016).

When the literature is examined, it has been observed that the number of STEM studies has increased in recent years. It was observed that the researchers focused on the STEM approach's interest in academic achievement (İzgi, 2020), permanence (Karadeniz, 2019), STEM attitude (Şirin, 2020) and STEM career fields (Daymaz, 2019). However, it was observed that researchers began to examine 21st century skills, students' self-efficacy and scientific creativity (Benek, 2019; Değirmenci, 2020; Sarıçam and Yildırım, 2021). In this study, the effect of STEM applications on students' scientific process skills in science class and how students' performance during the process were examined. The effect of STEM applications on scientific process skills was examined in different samples such as preschool students (Ünal, 2019), primary school students (Kavak, 2019), secondary school students (Yllmaz, 2019; İzgi, 2020) and teachers (Kale, 2019). Examination of STEM performances of students is available in the literature, although there is a small number (Şen, 2018; Smith, Hao, Dennen, et al., 2020).

In this study, "How is the effect of science teaching supported by STEM applications on the scientific process skills and STEM-related performance of secondary school sixth-grade students?" question has been investigated.

Answers were sought for the following sub-problems;

1) Does science teaching supported by STEM applications have an effect on the scientific process skills of sixth-grade students?

2) What are the performances of sixth-grade secondary school students in the science teaching process supported by STEM applications? 


\section{Method}

The concurrent nested mixed method, one of the mixed method designs, was used in this study. In the quantitative part of the study, one of the experimental designs, one group pretestposttest design was used. The study group of the research consisted of 35 students studying in the sixth-grade at a public secondary school in the Küçükçekmece district of Istanbul province, Turkey in the spring semester of the academic year of 2018-2019. The teacher who teaches to groups is also one of the researchers. For this reason, the sample was selected with convenient sampling method. Students were determined from ready groups and the research was carried out with a single group. "Scientific Process Skills Test" and "Activity Sheets" were used as data collection tools used in the study. The research has been done within the scope of "Force and Motion" unit. In practice, the "Scientific Process Skills Test" was applied to the students as a pre-test. Since group work will be done later, the class is divided into six groups in total. The implementation took place within a period of six weeks. Three STEM course activities were conducted. Activities were carried out in the classroom and outside the classroom. At the end of the application, "Scientific Process Skills Test" was applied to the students as a post-test. In order to learn the performance of students in the learning process, "Activity Sheet" was applied to the students in the application process.

\section{Conclusion, Discussion and Recommendations}

At the end of the research, it was determined that science teaching supported by STEM applications has a positive effect on scientific process skills. As a result of the study, it can be said that science teaching supported by STEM applications improves the scientific process skills of secondary school students. The rubric results (items 1, 2, 8, and 10) used in activity paper analyzes also support this judgment. When the rubric scores were examined, it was determined that the performance of the students was above the middle. As a result, it was seen that the students successfully used their STEM activities and scientific process skills and engineering skills. In the analysis of the activity papers used in the application, it was determined that the students performed lower than the other items in determining the problem statement and finding a solution to the determined problem. However, they still generally have a performance above the middle. In addition, it was observed that the students obtained high scores in the experimental processes. It can be said that science teaching supported by STEM applications has a positive contribution to the development of students' scientific process skills.

After the study, it is recommended to study the effect of STEM approach on different skills such as critical thinking, creativity, collaborative work and entrepreneurship among 21 st century skills. 